\title{
A Cooperation Project in Lesotho: Renewable Energy Potential Maps Embedded in a WebGIS Tool
}

\author{
Francesco Pasanisi ${ }^{1, *}$, Gaia Righini ${ }^{1}$, Massimo D’Isidoro ${ }^{1}{ }^{\mathbb{C}}$, Lina Vitali ${ }^{1}$, Gino Briganti ${ }^{1}{ }^{\mathbb{D}}$, Sergio Grauso ${ }^{1}$, \\ Lorenzo Moretti $^{1}$, Carlo Tebano ${ }^{1}$, Gabriele Zanini ${ }^{1}$, Mabafokeng Mahahabisa ${ }^{2}$, Mosuoe Letuma ${ }^{2}$, \\ Muso Raliselo ${ }^{3}$ and Mokhethi Seitlheko ${ }^{3}$
}

1 Department for Sustainability, ENEA-Italian National Agency for New Technologies, Energy and Sustainable Economic Development, 00123 Roma, Italy; gaia.righini@enea.it (G.R.); massimo.disidoro@enea.it (M.D.); lina.vitali@enea.it (L.V.); gino.briganti@enea.it (G.B.); sergra56@gmail.com (S.G.); lorenzo.moretti@enea.it (L.M.); carlo.tebano@enea.it (C.T.); gabriele.zanini@enea.it (G.Z.)

2 LMS-Lesotho Meteorological Services, Maseru 100, Lesotho; mahahabisa@gmail.com (M.M.); emletuma35@gmail.com (M.L.)

3 DoE-Department of Energy, Lesotho Ministry of Energy and Meteorology, Maseru 100, Lesotho; mraliselo@yahoo.co.uk (M.R.); seitlhekojerry@gmail.com (M.S.)

* Correspondence: francesco.pasanisi@enea.it; Tel.: +39-081-7723306

check for updates

Citation: Pasanisi, F.; Righini, G.; D'Isidoro, M.; Vitali, L.; Briganti, G.; Grauso, S.; Moretti, L.; Tebano, C.; Zanini, G.; Mahahabisa, M.; et al. A Cooperation Project in Lesotho: Renewable Energy Potential Maps Embedded in a WebGIS Tool. Sustainability 2021, 13, 10132. https:// doi.org/10.3390/su131810132

Academic Editor: Tomonobu Senjyu

Received: 28 July 2021

Accepted: 7 September 2021

Published: 10 September 2021

Publisher's Note: MDPI stays neutral with regard to jurisdictional claims in published maps and institutional affiliations.

Copyright: (c) 2021 by the authors. Licensee MDPI, Basel, Switzerland. This article is an open access article distributed under the terms and conditions of the Creative Commons Attribution (CC BY) license (https:/ / creativecommons.org/licenses/by/ $4.0 /)$.

\begin{abstract}
In this paper the background, activities undertaken, and main outcomes of the cooperation project "Renewable Energy Potential Maps for Lesotho" are presented. The project was launched in 2018 in fulfilment of the Paris Agreement by the Italian Ministry for the Environment and the Lesotho Ministry of Energy and Meteorology, with the aim to facilitate the local Government in the future planning and development of renewable energy in the country. A user-oriented WebGIS platform was utilised to share and analyse the outcomes of the project: a hydrological map to recognize potential areas for power generation; a wind atlas to identify specific sites with the most potential for wind energy generation; a solar radiation map, defining the different levels of radiation intensity, useful to localise sites for photovoltaic production. Human capacity building and technology transfer were carried out to strengthen the local expertise and ability to manage and plan renewable energy sources exploitation. The implementation of the project was based on a fruitful collaboration between scientists and stakeholders at the same time giving the local authorities a useful dataset and tool for renewable energy growth in Lesotho.
\end{abstract}

Keywords: Lesotho; renewable energy planning; sustainable development; Paris agreement; modelling assessment; GIS

\section{Project Assumptions and Background \\ 1.1. Energy Sector Status/Situation in Lesotho}

The Kingdom of Lesotho is a landlocked African state entirely surrounded by the Republic of South Africa, located between latitude $28-31^{\circ} \mathrm{S}$ and longitude $27-30^{\circ} \mathrm{E}$ (Figure 1a). It is the only country in the world entirely lying above $1000 \mathrm{~m}$ altitude. The area of Lesotho is $30,355 \mathrm{~km}^{2}$, mostly covered by natural vegetation (grasslands $49.6 \%$, shrublands $19.1 \%$, trees $1.3 \%$ ) and agricultural lands (18.9\%), with built-up areas accounting for $4.1 \%$ of the territory, barren lands $5.0 \%$, water bodies and rivers $0.9 \%$, and wetlands $1.1 \%$ [1]. According to the latest census carried out in 2016 [2], the population of Lesotho is 2,007,201 with a $0.68 \%$ annual growth rate compared to the 2006 census and an overall $107 \%$ increase compared to 1966 . About $34 \%$ of the resident population lives in urban areas, with a continuous significant increase of rural-urban migration over the last decades, while about $8 \%$ lives in peri-urban areas and $58 \%$ in rural areas. 


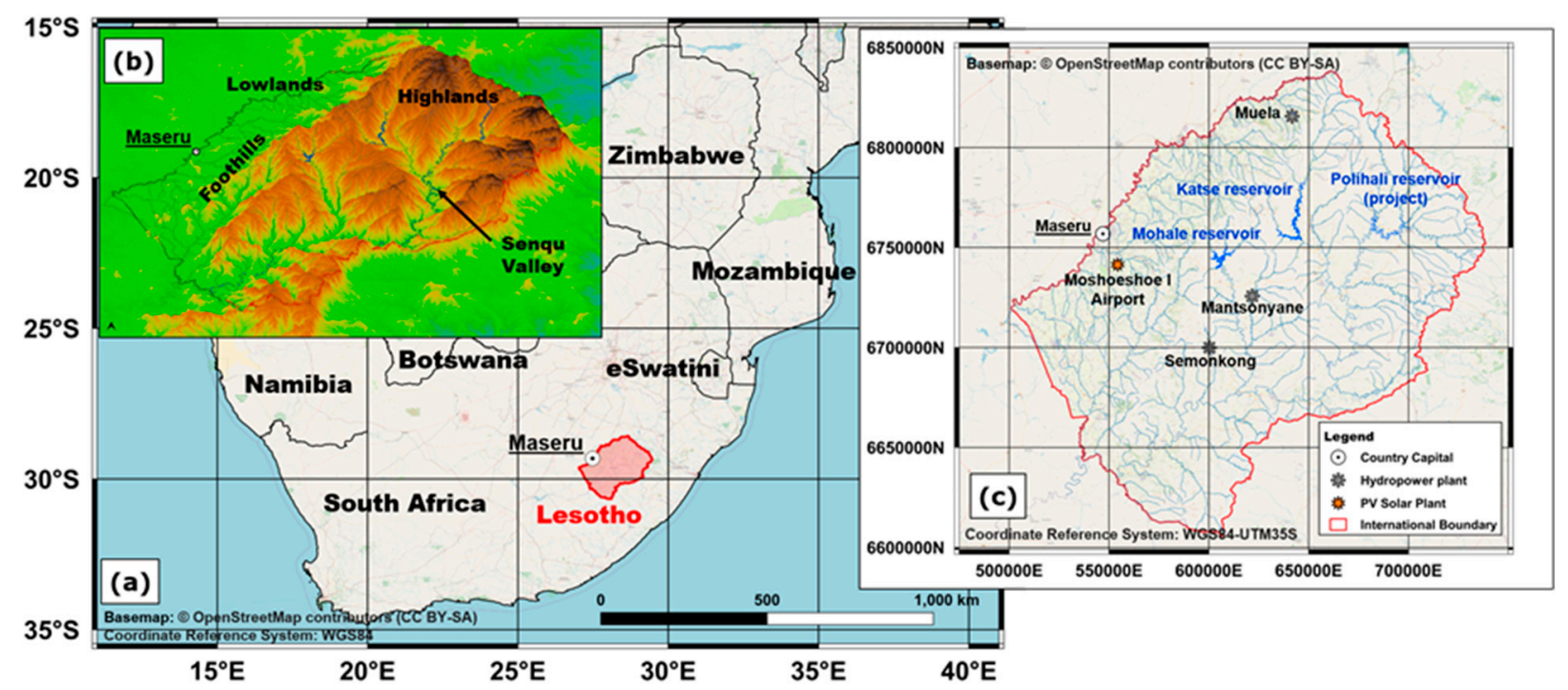

Figure 1. (a) Geographical setting of Lesotho; (b) general topography and morphological/ecological zones; (c) map of the main power plants and artificial reservoirs.

The territory of Lesotho can be divided into four different morphological and ecological zones (Figure 1b), namely: the Lowlands, the foothills, the mountains (or Highlands) and the Senqu/Orange river valley [3]. The Lowlands, covering $17 \%$ of the area of Lesotho, are the western part of the country, essentially consisting of plateaus with elevations in the range 1400-1800 $\mathrm{m}$ where the major urban centres (including the capital city Maseru) and the most arable lands are located. The foothills area ( $15 \%$ of the territory) is a transition zone between the Lowlands and the central and eastern parts of Lesotho occupied by the Highlands, the rugged Maloti/Drakensberg mountain range covering $59 \%$ of the country, where the highest peak in southern Africa is located (Thabana Ntlenyana, $3482 \mathrm{~m}$ ). The Maloti mountains are characterised by a number of river valleys, including the Senqu/Orange valley, with extension equal to about $9 \%$ of the country.

The Muela hydroelectric plant, completed in 1998 and located close to the northern boundary of Lesotho (Figure 1c), is the major power station of the country with an installed capacity of $72 \mathrm{MW}$ [4]. Minor plants [5,6] are located at Semonkong (hydro 0.18 MW, diesel $0.50 \mathrm{MW}$ ) and Mantsonyane (hydro $2.00 \mathrm{MW}$ ), whereas a $0.50 \mathrm{MW}$ hydro plant is located at Katse dam and serves essentially for dam operations. A solar photovoltaic (PV) $0.28 \mathrm{MW}$ plant is located at Moshoeshoe I International Airport [7] and a $2.4 \mathrm{~kW}$ small PV installation is in Roma at the National University of Lesotho.

The Muela power station is part of the Lesotho Highlands Water Project (LHWP) a large multi-phased infrastructure program established in 1986 by Lesotho and the Republic of South Africa with dual purpose: to provide water to Gauteng region in South Africa and to generate hydroelectric power for Lesotho. The part of the project that falls within Lesotho's territory is implemented by the Lesotho Highlands Development Authority (LHDA) [4]. In the Phase I of the LHWP project, the Muela plant was built, and Katse and Mohale dams were constructed along with water diversion works and other hydraulic infrastructures, giving rise to a system of interconnected artificial reservoirs [8-10]. In the ongoing Phase II of the project a third dam (Polihali) and other infrastructures are planned, along with a further hydropower plant for which different possible engineering schemes are under investigation. Despite concerns and debates [11,12] on costs and benefits of LHWP, discussing technical, economic, social and environmental aspects and considering also the huge size of the project, as a matter of fact the Muela power plant alone nowadays accounts for practically all the electricity produced in Lesotho, that is approximately in the range 500-530 GWh per year. 
Electricity supply in Lesotho has continuously increased over the last decades from about 200 GWh per year in 1990 to 900 GWh per year [13] (red line in Figure 2a), with average and peak load of 90-100 MW and 150-160 MW [14,15], respectively. Therefore, the electricity production in Lesotho is not sufficient to meet the internal demand and the deficit is compensated by imports from Eskom (South Africa) and EDM (Electricity of Mozambique), as illustrated in Figure $2 b$. The increase of electricity demand in Lesotho is associated with the growing rate of population with access to electricity that, according to the World Bank data [16] overall grew from 4\% in 2000 to $47 \%$ in 2018 (green line in Figure 2a), and other developmental activities with huge electricity usage. The electricity deficit is expected to further increase in the near future due to the expected growth of population, ongoing or planned electrification projects and growth of mining and other sectors. Projections from a recent study indicate a peak load in the range 527-684 MW and an annual electricity demand in the range 1706-4130 GWh by 2050 considering two different growth scenarios, referred to as "business as usual" and "high demand", respectively [17].

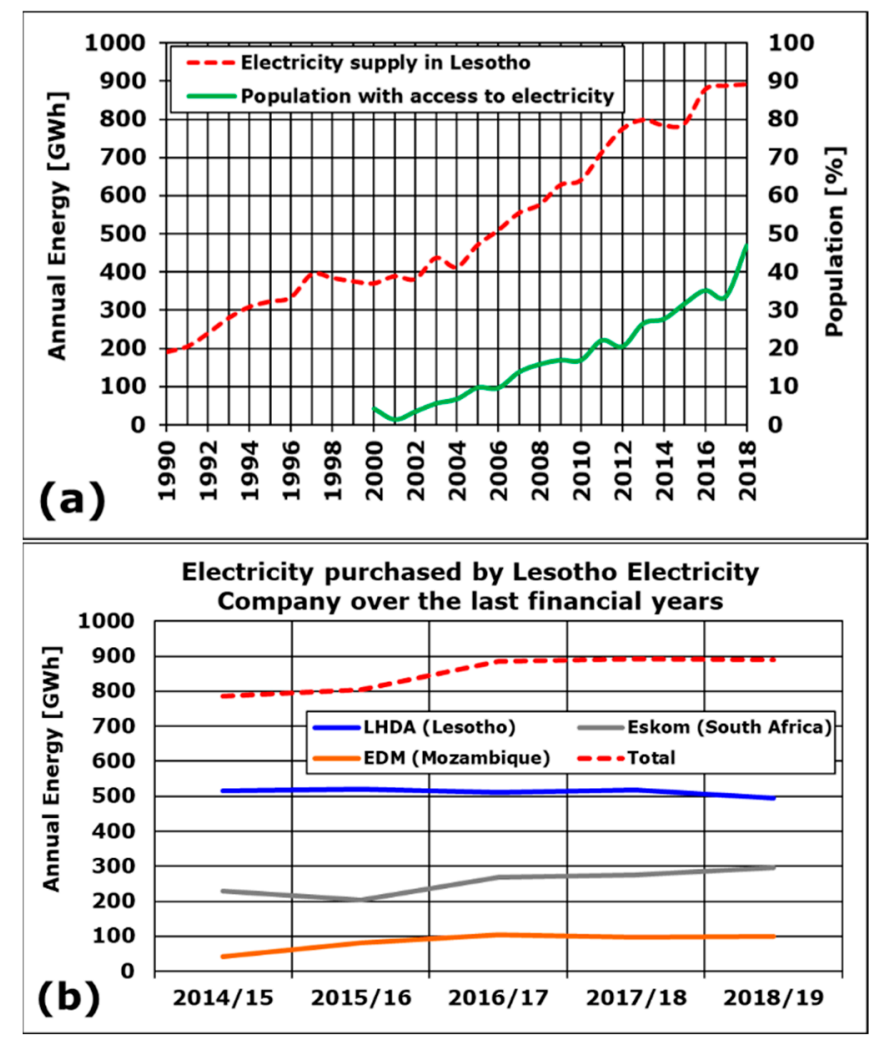

Figure 2. (a) Trend of electricity supply $[13,14]$ and rate of population with access to electricity [16] in Lesotho; (b) electricity purchased for distribution in Lesotho over the last financial years [14].

Figure 3a,b, respectively, illustrate the incidence of electricity obtained by different suppliers on the amount of distributed energy and on the costs sustained by the Lesotho Electricity Company (LEC) for the financial year 2016/2017 [15]. It is noted that the cost of imported energy is significantly higher than the cost of internal production, so electricity from LHDA contributes $59 \%$ of the total energy demand but only $14 \%$ of the total expenses incurred by the utility for procurement of power. According to the same data, the cost of $1 \mathrm{kWh}$ energy imported from South Africa and Mozambique approximately exceeds by 7 and 12 times, respectively, the cost of $1 \mathrm{kWh}$ energy purchased from LHDA. 


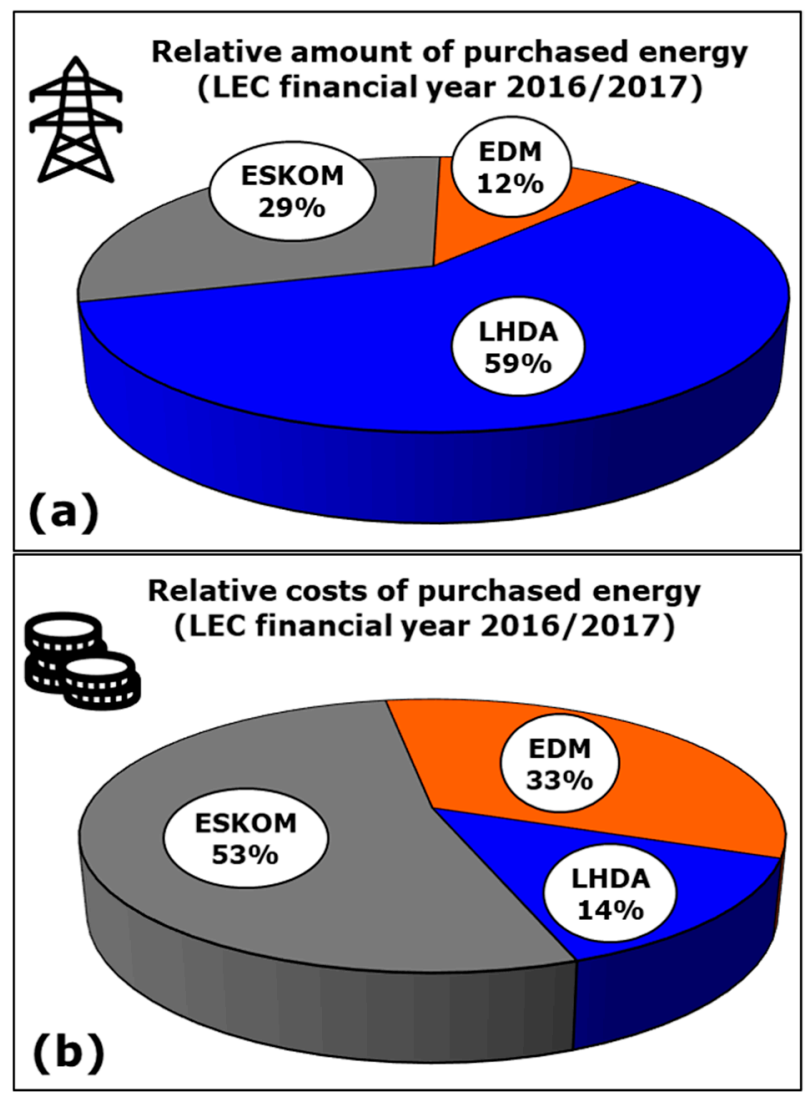

Figure 3. (a) Distribution of purchased electricity by supplier; (b) distribution of costs for electricity purchases by supplier. Data from Lesotho Electricity Company (LEC) [15].

The composition of energy consumption in Lesotho by different sources is illustrated in Figure $4 a, b$ for the reference year 2017 [13,18]. Figure $4 a$ refers to the total energy consumption from all economic sectors i.e.: manufacturing, construction, mining, transport, agriculture, commerce, public institutions, and households. It is noted that electricity accounts for only $5 \%$ of the total energy consumption in Lesotho, whereas the main contributors to the energy balance are: coal (essentially used by manufacturing and mining sectors), oil (all oil-derived fuels and products as gasoline, LPG, paraffin, etc.) and biomass (fuelwood, shrubs, crop waste and animal dung). Figure $4 \mathrm{~b}$ refers to energy consumed by households only: also in this case electricity accounts just for a little part of energy consumption, while the energy balance is by far dominated by biomass, essentially used for heating and cooking (along with charcoal and LPG), whereas paraffin and candles overall represent the main energy sources for lighting [19].

\subsection{Challenges and Opportunities}

From the above introduced data, the main challenges to be faced by Lesotho in the energy sector can be summarized as follows:

- Low electricity access rate. Despite the recent considerable growth, the overall electricity access rate in Lesotho does not exceed $50 \%$ of population. In addition, the households' electrification is not equally distributed over the country, with access rates estimated at $71 \%$ in urban centres and 38\% in rural areas, according to 2018 World Bank data [16].

- Non-self-sufficiency to satisfy the internal energy demand. The major internal energy sources in Lesotho are biomass, in all forms, and hydropower. Fossil fuels are totally imported from South Africa. Lesotho imports about $40 \%$ of electricity to meet the electricity demand [14,15], while considering the overall energy balance the dependency rate exceeds $60 \%$ [13]. The energy demand in Lesotho is expected to grow and 
likewise the energy deficit is expected to worsen in coming years. Besides the high costs of fuels purchased in foreign currency, the huge dependency on imports on petroleum products poses serious concern on the security of these products.

- Unsustainable use of biomass. The over-reliance on biomass for households' needs is leading to an excessive exploitation of biomass resources. In particular, the over harvesting of fuelwood is likely to activate deforestation, considering the limited extent of forest cover in Lesotho. On the other hand, the use of alternative biomass sources as agricultural residues or cattle dung deprives the agricultural land of natural manure, with negative impact on soil quality and fertility. Moreover, using biomass for heating and cooking produces high levels of indoor air pollution. According to World Health Organization (WHO) [20], 3.8 million people a year die prematurely in the world from diseases attributable to the exposure to indoor air pollution caused by harmful cooking practices.

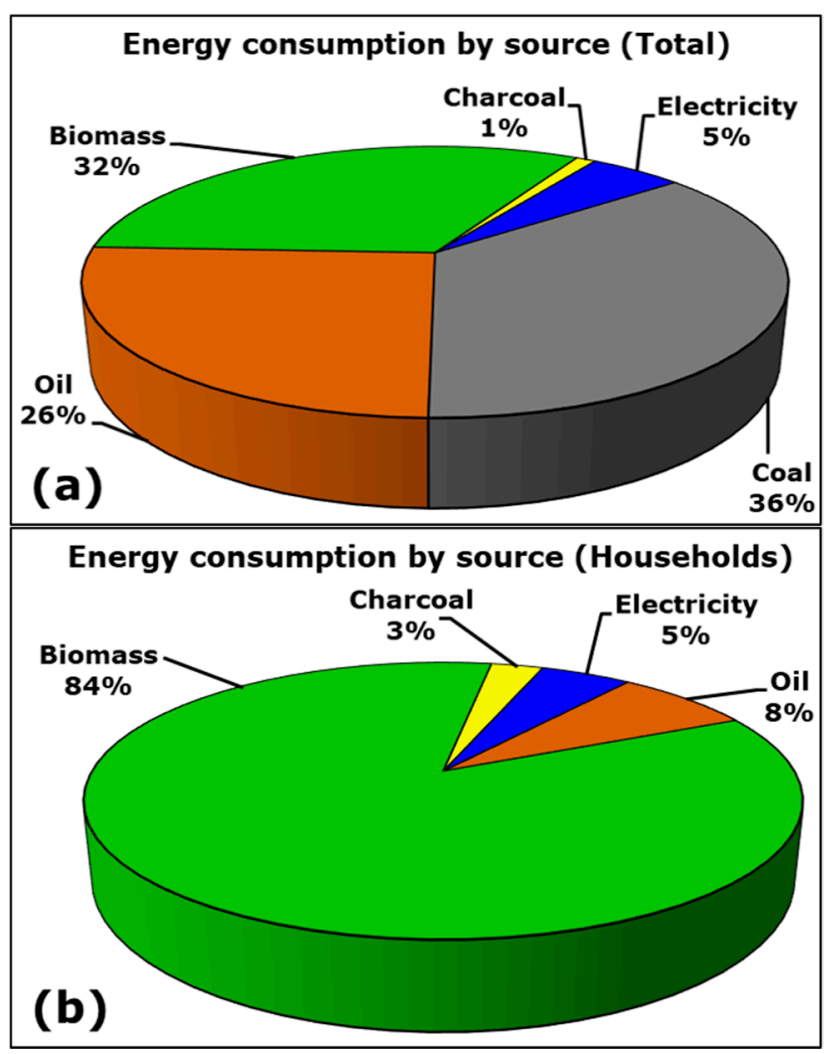

Figure 4. Distribution of energy consumption by source in Lesotho in 2017: (a) total consumption; (b) consumption for households' needs only. Data from the United Nations [18].

The key issue to cope with the above challenges is to enhance the use of electricity overall as an energy source. In this regard, over the last decades a great effort was devoted by Lesotho's institutions and stakeholders to electrification projects, funded both with internal resources and from international cooperation programmes, with a particular attention to rural areas. It is worth noting that electricity access rate in rural areas of Lesotho (38\%) is greater than the average value for Sub-Saharan Africa, estimated as 27\% [16]. At the same time, in order not to worsen the energy deficit the desired increase of electricity demand should be supported by an adequate increase of the internal electricity production.

The increase of electrification in Lesotho poses serious technical and economic challenges due to large rural areas of the territory covered by rugged and barely accessible mountains, with sparsely populated villages typically located on steep mountain sides or narrow river valleys. In addition, the spread of electricity by grid expansion in rural areas typically requires huge economic investments against expected limited revenues 
from electricity sales, also considering the low income of rural households. The difficulties in energy distribution affects, in turn, the discussion on how to effectively increase the national electricity production, in addition to the already planned Phase II of LHWP. These topics were extensively addressed by policymakers, stakeholders, practitioners and scholars, and different solutions were proposed [17,21-25]. Despite a certain lack of general consensus, the following points are currently assumed as fundamental for electricity expansion planning in Lesotho:

- Increasing the overall local electricity production using Renewable Energy (RE) sources (hydro, solar and wind).

- Implementing the Electrification Masterplan which advocates for a two-pronged strategy: grid extension and off-grid solutions including mini-grids and stand-alone systems.

The above points are recognized in the recent Lesotho Renewable Energy-Based Rural Electrification Project (LREBRE) [26] under implementation, in the proposed Scaling Up Renewable Energy Program in Low-Income Countries (SREP) Investment Plan [27] and, more in general, in the major policy statements and action plans adopted by the Lesotho Government and authorities [28-31]. From a technical standpoint RE sources appear particularly suited to the context of Lesotho because of the scalability of technical solutions available for energy production, that may range from large scale on-grid plants to distributed off-grid solution as mini- and micro-hydro, solar home systems (SHS) or small wind turbines.

Considering the above challenges and the policies adopted by the Lesotho energy sector focused on the use of RE sources, the following main opportunities can be recognized:

- An abundance of local RE sources (hydro, solar and wind), still largely unexploited.

- A possibility to match the development of the national energy sector with environmental policies aimed to preserve the environment from degradation and implement climate change adaptation and mitigation strategies, with access to international cooperation programs.

Water can be considered the most important natural resource in Lesotho, which has a wide hydrographic network, high terrain altitudes, and a relatively large amount of precipitation. Mean annual rainfall over the country is about $800 \mathrm{~mm}$, with precipitations mostly concentrated in the foothills and Highlands (up to $1600 \mathrm{~mm}$ per year) where elevation gradients are most pronounced. The possibility to exploit the huge hydropower potential in Lesotho has been long investigated since the 1950s [4] leading to both the design and implementation of the large-scale LHWP and several feasibility studies on small hydropower plants [32]. More recent studies investigated the state of the art and prospects for hydropower generation in Lesotho [33] focusing in particular on the possible sites suitable for small- (up to $10 \mathrm{MW}$ ) and mini- (up to $1 \mathrm{MW}$ ) hydropower development [34], that were proposed in the SREP Investment Plan [27] along with micro-hydro floating solutions (up to $100 \mathrm{~kW}$ ). Despite the great potential, hydropower development is hindered by economic, social, and technical barriers, among which it is worth mentioning the siltation of reservoirs due to an intense soil erosion and sediment transport. As a matter of fact, only two of the four small hydro plants built in the 1980s and 1990s are currently operating and almost all small artificial reservoirs experienced severe siltation problems.

Solar energy has been long identified as one of the most interesting solutions for electrification in Lesotho, especially in rural areas [22,23]. Estimation of solar radiation in the country and on specific sites were performed since the 1980s using both mathematical models and measurements data [35-38], indicating that Lesotho has a great potential in terms of solar energy development, with more than 300 days of sunshine per year and more than $10 \mathrm{~h}$ of light per day on average. Recently proposed electrification projects [26] include utility-scale photovoltaic (PV) solar park, small scale PV micro-grid and PV SHS off-grid solutions, for which solar insolation data were derived from the VAISALA/IRENA Global Solar Dataset at $3 \mathrm{~km}$ resolution [39]. Despite the quite ideal conditions for solar technologies development in Lesotho, several technical and economic barriers hampered 
progress, these include the availability of materials and know-how, and the limited financial capabilities of potential investors and households.

As for wind energy, not much is reported in literature about the available potential in Lesotho. Wind profile assessments at three sites (Masitise, in the south, Letseng, in the north and Sani, in the east of Lesotho) were performed based on 2-year anemometric data [40,41], revealing a sufficient potential for electricity generation. The $35 \mathrm{MW}$ Letseng windfarm project made some technical progress, despite concerns initially raised on the impacts on endangered vulture species. Other feasibility studies were performed at different sites [27] but, to date, no windfarm is operating. In general, greater reservations were expressed in the past about wind power resources than about hydro and solar power [22]. This can be ascribed both to perceived uncertainties on the effective availability of wind and to environmental/ecological issues.

Development strategies of the energy sector focused on REs may provide great opportunities for international cooperation in terms of financial and technical support, as they match with the major well-established international agreements and policy statements. A milestone in this sense is the Paris Agreement (PA) [42], adopted by 196 countries in December 2015 at the 21st Conference of Parties (COP 21) to the United Nations Framework Convention on Climate Change (UNFCCC) [43]. The PA commits the parties worldwide to implement policies aimed at reducing GHGs emissions to limit global warming and provides a specific framework for financial, technical, and capacity building support to those countries who need it. The obligations of developed countries to sustain the efforts of developing countries in climate changes adaptation and mitigation policies are strongly emphasized as well as cooperation programs aimed at technology development and transfer, training, education and improving access to information.

More in general, the development objectives of the Lesotho energy sector are in line with the 2030 Agenda for Sustainable Development [44], adopted by the United Nations Member States in 2015. The Agenda is a 15-year world action plan aimed at eradicating poverty, protecting the planet from degradation, ensuring sustainable economic, social, and technological progress and fostering peace and justice. These aims are described by the well-known 17 Sustainable Development Goals (SDGs) and 169 associated targets, for which specific progress indicators are defined [45]. The fundamental role of international cooperation to sustain the efforts of least developed countries, with special attention to Africa and landlocked countries is well recognized in the Agenda. In particular, the following SDGs appear to be mostly addressed in the energy development policies of Lesotho:

- $\quad$ SDG 1. End poverty in all its forms everywhere.

- $\quad$ SDG 3. Ensure healthy lives and promote well-being for all at all ages.

- $\quad$ SDG 5. Achieve gender equality and empower all women and girls.

- $\quad$ SDG 7. Ensure access to affordable, reliable, sustainable and modern energy for all.

- SDG 11. Make cities and human settlements inclusive, safe, resilient and sustainable.

- $\quad$ SDG 13. Take urgent action to combat climate change and its impacts.

The above list is unavoidably subjective and not exhaustive, because SDGs are inherently connected to each other and energy policies either directly or indirectly affect all of them. A point-by-point discussion would be too long and somehow trivial. Briefly, energy development policies of Lesotho are clearly in line with SDG 7 and, focusing on REs, they address SDG 13, as well. Moreover, it is worth noting, as for SDG 1, that the greatest part of population with no access to electricity normally belongs to the poorest households, especially in rural areas where everyday life can be very difficult, and that the lack of adequate and clean sources of energy is frequently compensated by an excessive consumption of women's labour and women's time [46], directly addressing SDG 5. It is also to be observed that, as already stated, the burning of biomass for cooking and heating in houses with inadequate ventilation may induce high levels of indoor air pollution with concerns for human health (SDG 3 and SDG 11). 


\section{The Project "Renewable Energy Potential Maps for Lesotho"}

Considering the context described above, in fulfilment of the PA [42], under the UNFCCC [43] the Governments of Italy and Lesotho in 2016 signed a Memorandum of Understanding (MoU) on "Co-operation in the field of climate change vulnerability, risk assessment, adaptation and mitigation". The deployment of RE was identified in the MoU as a priority sector of cooperation. Therefore, in 2018 a Joint Committee composed of the Italian Ministry for the Environment, Land and Sea (IMELS) and the Lesotho Ministry of Energy and Meteorology, launched the project "Renewable Energy Potential Maps for Lesotho" with the aim to produce maps to assist the Government of Lesotho in the future planning and development of RE exploitation. The implementation of the project officially started in March 2018 with a scheduled duration of 2 years, until March 2020. From the Lesotho Government, the two official Institutions participating to this project were the Ministry of Energy and Meteorology of the Kingdom of Lesotho-Department of Energy and the Lesotho Meteorological Services (LMS). However, it should be noted that other stakeholders were involved during the whole activities and in particular in the final phase including technology transfer and local human capacity building.

The scope of this project was to produce renewable energy potential maps for Lesotho to assist the Government in the planning and development of renewable energy exploitation and to achieve a concrete step towards attaining a low-emission development pathway. Indeed, the availability of accurate and reliable information plays a key role in the decisionmaking process [47]. In the present case, an energy sector assessment was recognized as essential and it covered different renewable sources such as hydrological, wind and solar. In summary, therefore, the project focused on the following activities:

- To develop a hydrological map of Lesotho, useful to identify potential sites for power generation.

- To develop a wind atlas for Lesotho, useful to identify specific sites with the most potential for wind energy generation.

- To develop a solar radiation map, defining the different levels of radiation intensity over Lesotho, useful to localise sites for photovoltaic production.

The potential energy maps were embedded in a WebGIS based tool containing further data suitable for the identification of sites which are promising for exploitation. Moreover, other ancillary georeferenced data (i.e., topographic maps, geological maps, land cover, etc.) were separately provided to the stakeholders, as an add-on product. Consistently with the general philosophy of the cooperation program, in order to make the technology transfer easier, free and open-source software was used for the needs of the project, i.e., for meteorological simulations, geoprocessing, and mapping. Indeed, the project promoted capacity building and skills transfer in order to strengthen the local expertise and make the Lesotho Government able to manage the supplied tool.

The project was composed of six work packages, as listed below:

- WP0: Project management

- WP1: Wind energy map for Lesotho

- WP2: Solar energy map for Lesotho

- WP3: Hydrological map for Lesotho

- WP4: GIS database-WebGIS

- WP5: Human capacity building

It is worth noting that the installation of wind turbines and ground-mounted solar panels and the development of hydropower infrastructures could lead to some level of risks to nature and ecosystems. The optimization in site selection, using suitable mapping and strategic and environmental impact assessment, is a fundamental best practice, whereas inappropriate siting can trouble valuable habitats. Indeed, the exploitation of renewable energies should give special attention to environmental impacts during planning and should be viewed together with the technical, economic, social, cultural, and political factors, which influence planning decisions, including the analysis of the possible risks that could affect the 
performance and profitability of the project [48]. These evaluations were out of the scope of the "Renewable Energy Potential Maps for Lesotho" project which, instead, represents the starting point giving the basic tools for further investigations on impacts and solutions concerning RE planning and deployment.

The present paper illustrates the aforementioned project. In detail, the focus is on the general aspects of the project and its potential in establishing a shared knowledge base to support stakeholders in managing and planning renewable energy sources exploitation. A detailed discussion of RE potential maps is not the aim of this paper. In Section 3 the modelling setup, the data processing and the developed tools are described. In Section 4 the main results of the project are illustrated, in terms of both the production of a comprehensive database for RE mapping and the final goals of human capacity building and skills transfer. Finally, Section 5 summarises points on evaluation and conclusions and makes recommendations for consideration for further developments.

\section{Materials and Methods}

\subsection{Wind and Solar Resources Estimation}

In order to estimate the photovoltaic and wind power potential over Lesotho, the Weather Research and Forecasting (WRF) numerical model was used. In particular, a specific augmentation of WRF, the WRF-SOLAR [49] was adopted, which is based on version 3.6 of WRF-ARW [50].

WRF-SOLAR is an important component of the National Center for Atmospheric Research's (NCAR) SunCast Solar Power Forecasting [51] and is specifically designed to make the WRF model appropriate also for solar power forecasting. In this respect, some applications can be found in [52-54].

Moreover, WRF is a state-of-the-art model widely used not only for weather related topics but also for wind energy applications (among the more recent works: [55-58]).

In this context the model was applied at high horizontal resolution $(1 \mathrm{~km})$ over Lesotho covering a temporal period of 30 years, from 1989 to 2018, to provide a robust estimation of wind and photovoltaic energy resources.

\subsubsection{Modelling Setup and Data}

As a preliminary step, to the scope of choosing the best model configuration for our purposes, a yearly simulation was repeated using three different combinations of some relevant parameterisations available in WRF, supposed to produce a variability of the results for either wind or solar radiation.

To evaluate the model results, the observational data of wind and solar radiation were collected from the Lesotho authorities to be compared to the corresponding modelled quantities. The period to be simulated was chosen among the more recent years maximising the availability of wind and solar radiation measurements, with a preference on hourly quantities aiming to reproduce the diurnal cycle with the model. Key contributors of observations data were LMS and LHDA. In particular, LHDA provided hourly measurements of radiation and wind at Katse and Mohale dams from 2011 to 2016, while data from LMS came from 13 sites, spanning a larger time period (1980-2015) but on a daily basis and only for two parameters: daily maximum and minimum temperatures and accumulated precipitation. Analysing the collected data, 2015 resulted in being the year with the maximum availability of hourly observations so that it was used to perform the test simulations for the model setup tuning. The three different model configurations tested are listed in Table 1, together with the correspondent number, in brackets, set in the WRF namelist (see for reference WRF model manual, Section 5 [59]). 
Table 1. Weather Research and Forecasting (WRF) parameterisations setting for the three simulations (labelled Sim1, Sim2 and Sim3, respectively) conducted over Lesotho for year 2015. In brackets are the numbers corresponding to the model namelist selection [59].

\begin{tabular}{cccc}
\hline & Sim1 & Sim2 & Sim3 \\
\hline Long wave & RRTMG (4) & RRTMG (4) & RRTM (1) \\
Short Wave & RRTMG (4) & RRTMG (4) & Dudhia Scheme (1) \\
Surface Layer & Eta Similarity (2) & MM5 similarity (91) & Eta Similarity (2) \\
Planetary Boundary & Mellor-Yamada-Janjic (2) & Yonsei University scheme (1) & Mellor-Yamada Nakanishi and \\
Layer & WRF Single Moment 6-class (6) & WRF Single Moment 5-class (4) & New Thompson et al. scheme (8) \\
Microphysics & Noah (2) & Noah (2) & Noah (2) \\
Land Surface Model & 35 & 41 & 35 \\
Number of & & & \\
vertical levels & & & \\
\hline
\end{tabular}

The model was run adopting a two-way nesting with three domains at horizontal resolutions of 15, 3 and $1 \mathrm{~km}$, respectively. The parent domain was forced by 3 hourly ECMWF ERA5 fields at $0.3^{\circ}$ resolution [60]. Figure 5 reports the WRF simulation domains.

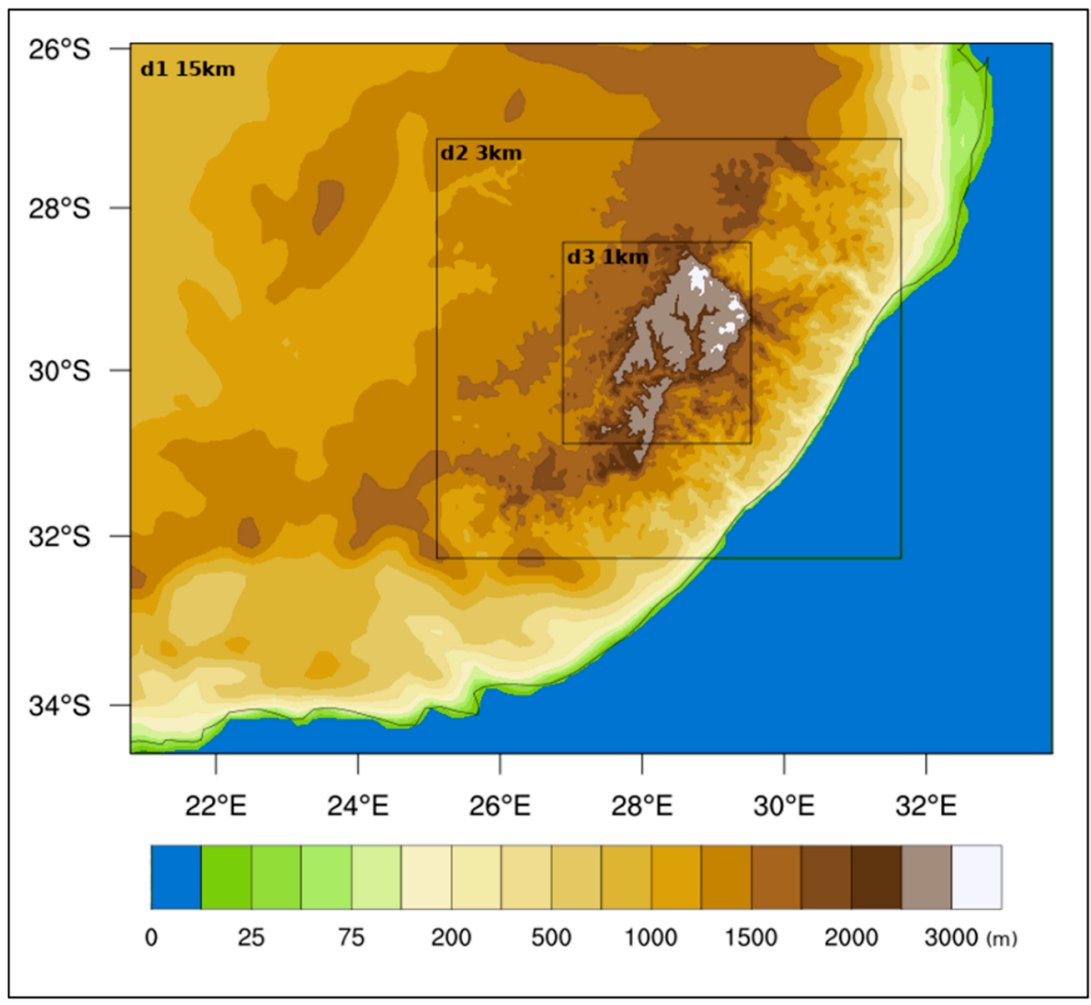

Figure 5. WRF nested domains location and orography.

After comparing modelled data with observations, the best performing WRF setup resulted in being Sim2, as labelled in Table 1. This configuration was then adopted to perform the multiannual assessment of wind and solar photovoltaic energy resources. Details on the comparison between modelled and observed hourly and aggregated data is given in [61], where a preliminary estimation of wind and photovoltaic potential over Lesotho was presented based on the 2015 simulation.

\subsubsection{Multiannual WRF Simulation for the Estimation of Wind and Solar Data}

In order to obtain renewable energy estimation that is representative of the interannual variability of meteorological conditions in Lesotho, a 30-year simulation covering the period 1989-2018 was conducted using the WRF settings defined above. 
The implemented modelling chain consisted of single $30 \mathrm{~h}$ simulations restarted every day at $18 \mathrm{UTC}$ using the ERA5 reanalysis at the boundary of the parent domain, considering the first $6 \mathrm{~h}$ as a spin-up period. Then, hourly model outputs of the following day from 00UTC to 23UTC were retained every day.

The computing effort to accomplish the 30-year period simulation was supported by the ENEA HPC facility CRESCO (Computational RESsearch Centre on COmplex systems) $[62,63]$. One year simulation took about 25 days CPU time and approximately 2 TB data occupation on the high-performance file system connected to the machine, with a total of $60 \mathrm{~TB}$ for the whole period. The $30 \mathrm{~h}$ simulations were run on 192 cores independent of each other and thanks to the CRESCO computing power capability ( 10,000 cores) it was possible to perform all the period in a few months, running more days in parallel, even considering the queue management system allocating the resources to all the daily CRESCO users.

Once the whole period was completed, the $1 \mathrm{~km}$ resolution WRF 3-dimensional fields in output were post-processed to obtain hourly values of the quantities needed for energy potential estimations. In particular, wind speed and air density, interpolated at four different heights above ground $(50 \mathrm{~m}, 100 \mathrm{~m}, 150 \mathrm{~m}$ and $200 \mathrm{~m}$ ) were extracted for wind energy estimations, while $2 \mathrm{~m}$ air temperature and ground solar radiation were used for photovoltaic estimations, as described in detail in the following paragraphs.

\subsubsection{Wind Power Production Estimation}

Starting from meteorological model output, several variables were computed, describing both wind energy availability and the efficiency of its exploitation.

First, wind power density (i.e., air mass kinetic energy, hereinafter WPD) was evaluated as the most straightforward parameter in order to assess wind energy availability in an area [64]. More in detail, hourly 3-dimensional wind speed and air density fields produced by WRF model, were used to evaluate WPD for the whole 30-year period (1989-2018), at an hourly time interval, and for every grid point of the domain covering Lesotho at $1 \mathrm{~km}$ resolution. In order to cover the range of typical hub heights of current commercial wind turbines, WPD was computed at four different levels above the ground: $50 \mathrm{~m}, 100 \mathrm{~m}, 150 \mathrm{~m}$ and $200 \mathrm{~m}$, vertically interpolating wind speed and air density fields from hybrid pressure model levels to the selected heights. Once hourly evaluation was available, an overall period assessment was carried out. First, hourly WPD yearly averages were computed for each of the 30 years at the selected heights for every grid point. Then, some statistics over the 30 annual values were computed, at each level and grid point, such as average, minimum, maximum and standard deviation. Daily modulation and yearly variability of energy assessment were investigated too, by means of heatmaps elaboration [65], thus allowing, for each point of the domain, a quick identification of the period both of the year and of the day with maximum energy availability.

Indeed, not all the energy available in the wind can be extracted and the actual energy exploitation depends on how efficiently the system converts wind kinetic energy into electrical power. In order to estimate the final energy production, technical details on the wind generator have to be assumed. These include its power curve i.e., how large the electrical power output would be at different wind speeds (e.g., [61,66]). Technical data describing real-world wind turbines features were used, being the choice of the turbines taken into account based on both worldwide market penetration and data availability. Indeed, state-of-the-art commercial wind turbines were chosen covering all wind classes and a large variety of rotor sizes. Given the power curves of the chosen wind turbines and using hourly wind speed from WRF, interpolated at the hub height, hourly values of the energy expected from each turbine for the whole 30-year period were obtained at every grid point of the domain. Once hourly evaluation was available, the period evaluation was carried out: hourly values were integrated over the time in order to obtain the accumulated energy production (AEP) for each of the 30 years. In addition, capacity factors (CF) were also computed by dividing each annual energy output by the theoretical maximum output, 
that is if the machine was running at its rated (maximum) power during all the hours of the year. Finally, as for WPD, the same statistics over the 30 annual values were computed for both $\mathrm{AEC}$ and $\mathrm{CF}$, obtaining for each turbine the minimum, maximum, average and standard deviation fields in the whole domain.

\subsubsection{Photovoltaic Power Potential Estimation}

Starting from WRF output fields - in particular ground albedo and hourly radiation data on a horizontal surface-solar energy evaluation on a tilted surface was assessed in terms of both energy availability and conversion efficiency.

This included total solar radiation incident on a tilted surface estimated as the sum of three components, i.e., direct, diffuse and reflected [67,68]. Assessment was carried out assuming diffuse radiation being uniformly and isotropically distributed over the sky dome according to Liu and Jordan [69] and photovoltaic modules being set in the optimal configuration, i.e., facing the equator. More details on the formulations used for the assessment can be found in [61]. Concerning the module inclination with respect to the horizontal plane, its best value, maximizing the annual energy production, was computed by means of an optimization procedure and made available as an additional product in the framework of the project. The tilt angle depends indeed on the diffuse, reflected and direct radiation. In general, a high probability of cloudiness needs a small angle; a low cloudiness requires instead an angle approximately equal to the latitude.

The amount of total solar radiation, reaching the modules, is the most important factor in defining energy production of a PV system. Anyway, the final power output of the system depends on its conversion efficiency, which of course has to be evaluated too, in order to better support energy exploitation planning.

The energy conversion efficiency of a PV system depends on a number of different external factors. Some of them are "objective" factors, mainly depending on meteorological conditions and module type. Others depend on how the modules are installed, maintained, and cleaned. Moreover, several electricity and heat losses can be experienced by the system and finally, the power production of a PV system tends to decrease slowly with system age. Factors depending on specific installation and maintenance features were not considered in the context of this ex-ante evaluation since it is difficult to evaluate them a priori. System and ageing losses were not taken into account too, since useful information to calculate them rely on the end-user system configuration and a posteriori expert judgment is needed.

In summary, the only effects taken into account in estimating the actual PV power output were the main important "objective" ones, namely the reflectivity of the module surface and its temperature. More in detail, the effect of module surface reflectivity on PV energy conversion efficiency was taken into account following the approach of Martin and Ruiz [70,71]. Concerning PV efficiency variation with module temperature, the stateof-the-art approach, proposed in [72] and described in depth in [73], was adopted. The dependency of module temperature on ambient temperature, radiation and wind speed was described according to [74]. Since both the reflectivity of the module surface and its temperature depend on time, position and meteorological conditions, both of them were evaluated as a function of time and space, at hourly time step for the whole thirty years period, and for every grid point of the domain covering Lesotho a $1 \mathrm{~km}$ resolution.

Both total solar radiation and power output assessment was carried out at hourly time step. Integrating hourly data on a yearly basis, annual accumulated energy evaluation was obtained for each of the thirty years. As for wind power production estimation, some statistics over the thirty annual values were elaborated. In particular, the average of the 30 values was computed, providing the best estimation of annual energy production, based over 30 years, a long and statistically representative period. Minimum and maximum values along with the standard deviation were estimated too, providing the range of the inter annual variability to be expected. Finally, daily modulation and yearly variability of energy assessment were investigated too, by means of heatmaps elaboration. 


\subsection{Extraction of the Hydrographic Network}

The river network and catchment divides were derived from elevation data, described by a DEM (digital elevation model), using state-of-the-art geoprocessing tools operating in GIS Environment. Namely, the QGIS [75] software integrated with the TauDEM [76,77] suite of hydrological tools, both distributed as free and open-source software, were used in the present work. Results were validated by comparison with available cartographic and hydrographic data. Preliminary results of the present task were reported in [78].

\subsubsection{Data Collection and Preparation}

Since surface runoff is a gravity-driven process, topography is the basic input information needed to derive the hydrographic network. In the first step of the project, it was chosen to use the SRTM GDEM V3 (Shuttle Radar Topography Mission Global DEM, Version 3) at 1 arc-second resolution (about $30 \mathrm{~m}$ in projected coordinates) [79], based on Interferometric Synthetic Aperture Radar observations taken from the Space Shuttle Endeavour in February 2000 [80]. Elevation data are available for public download at the United States Geological Survey (USGS) EarthExplorer website [81] as a collection of $1^{\circ} \times 1^{\circ}$ GeoTIFF images. SRTM DEM was used to derive a preliminary hydrological map released as a mid-project outcome.

A more refined DEM was later derived from a highly detailed vector dataset of elevation contours provided by the Lesotho's Land Administration Authority (LAA), with typical interval between elevation contours of $2 \mathrm{~m}$ in the Lowlands and $10 \mathrm{~m}$ in the Highlands. Contour lines were interpolated to derive a $10 \mathrm{~m}$ resolution DEM covering the Lesotho territory, whereas SRTM DEM was used to cover the area of interest outside Lesotho boundary not covered by LAA data. This DEM was used in the final step of the project to derive the definitive hydrological map.

\subsubsection{Data Processing and Results Validation}

The extraction of river networks and catchment divides from a DEM entails a sequence of well-established procedures in the GIS environment. In the present work the following steps were performed using specific algorithms available in the TauDEM suite:

1. DEM pre-processing for pit removal;

2. Detection and mapping of flow directions;

3. Computation of contributing areas;

4. Stream definition by threshold;

5. Delineation of stream reaches and watersheds.

As for the Point 1, it is worth noting that the "pits" or "sinks" removed are to be intended as artefacts or outliers of the DEM due to anomalies in the digitisation or interpolation, that may induce unrealistic disconnections in the hydrographic network.

Flow direction moving from each cell of the DEM was computed using the classical "D8 method" [82]. Considering for each cell a $3 \times 3$ cells neighbourhood, it is assumed that water drains from the cell in the centre to one of its eight neighbouring cells, either adjacent or diagonal, following the direction along which the steepest downward slope is detected. Contributing areas, i.e., the number of cells contributing to drainage in each cell of the computational grid, were derived from the flow directions through an iterative algorithm.

A "threshold method" was adopted to identify the cells of the grid to be considered part of a stream of the hydrographic network. The threshold value i.e., the minimum number of contributing cells imposed for stream detection, was progressively adjusted comparing results of different computations with available cartography (topographic maps, vector datasets and satellite images), in a typical calibration/validation process (Figure 6). A threshold of 5000 cells, corresponding to a $0.50 \mathrm{~km}^{2}$ minimum contributing area, was finally adopted for the definitive map. This value was assumed as an optimal compromise between the need for an as-accurate-as-possible stream network and the practical needs to contain the computational time and the size of output files. Stream reaches and catchment divides were finally derived in vector format and included in the WebGIS. 


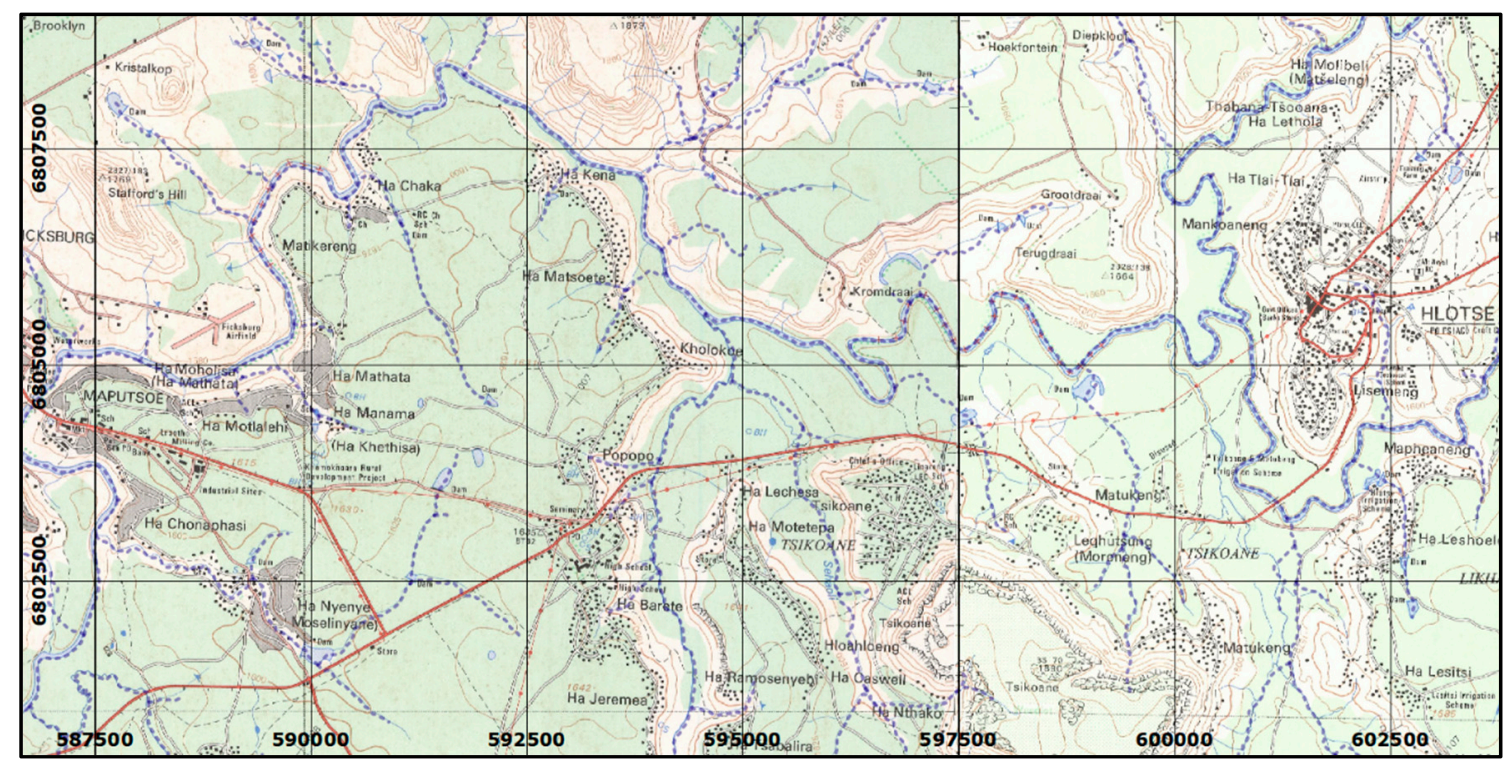

Figure 6. Example of comparison between the digital hydrographic network derived by DEM (dotted lines) with blue lines of topographic maps.

\subsection{WebGIS}

WebGIS generally means a user-oriented web mapping application mainly aimed at presenting, sharing, mining and analysing the results of a GIS. This tool enables a worldwide user to operate on GIS applications that are platform independent and available from every personal computer with an Internet browser.

Different types of users can obtain several advantages from a WebGIS according to their expertise such as basic, advanced, expert, and different roles such as technician, researcher, manager. Indeed, many GIS operations could be implemented in the web tool starting from the basic ones like visualization, overlay, selection, and reaching the advanced queries or processing operations. Moreover, a WebGIS can be dynamically updated in time with new data and upcoming requirements.

In order to visualize and manage the project products, a WebGIS platform was developed. The system was based on an Ubuntu Linux (version 18.04) machine, configured with the following open source software:

- $\quad$ Apache HTTP Server [83];

- QGIS, version 3.10.4 [75], with web server capabilities (QGIS server);

- $\quad$ Lizmap Web Client [84] to interface QGIS and the web.

To avoid managing a large number of layers, the contents were separated into distinct QGIS projects.

Any modification and update of a QGIS project can be done by the operator in its local machine and then uploaded to the server.

Details on the contents included in the WebGIS are described in the following section.

\section{Results}

\subsection{WebGIS Database for Managing and Planning Renewable Resources Exploitation}

An interactive WebGIS tool, including more than 120 data layers, was the final and comprehensive outcome of the project. Actually, all the developed maps describing spatial distribution of renewable resources were embedded into the WebGIS database. Additional products produced within the project were integrated too, together with available ancillary data, which could be useful for the identification of promising sites for renewable energy exploitation. At the end of the project, this tool and the whole dataset were completely delivered and entrusted to the main local beneficiaries and project partners: the Ministry 
of Energy and Meteorology of the Kingdom of Lesotho-Department of Energy and the Lesotho Meteorological Services.

\subsubsection{WebGIS Tool Structure and Content}

Figure 7 shows the landing page with the main graphical user interface (GUI) of the developed WebGIS tool. The home GUI page offers access to four main data sections. Three of them correspond to the renewable resources investigated within the project. Namely, they include the photovoltaic and wind energy maps, describing respectively the spatial distribution of solar and wind power energy availability, and the hydrological map, useful to identify potential sites for hydropower generation. Moreover, since the WRF model provides the whole atmospheric state, a fourth section was added including accumulated annual precipitation fields, which can be useful to deepen the assessment (e.g., follow-up of hydrological studies).

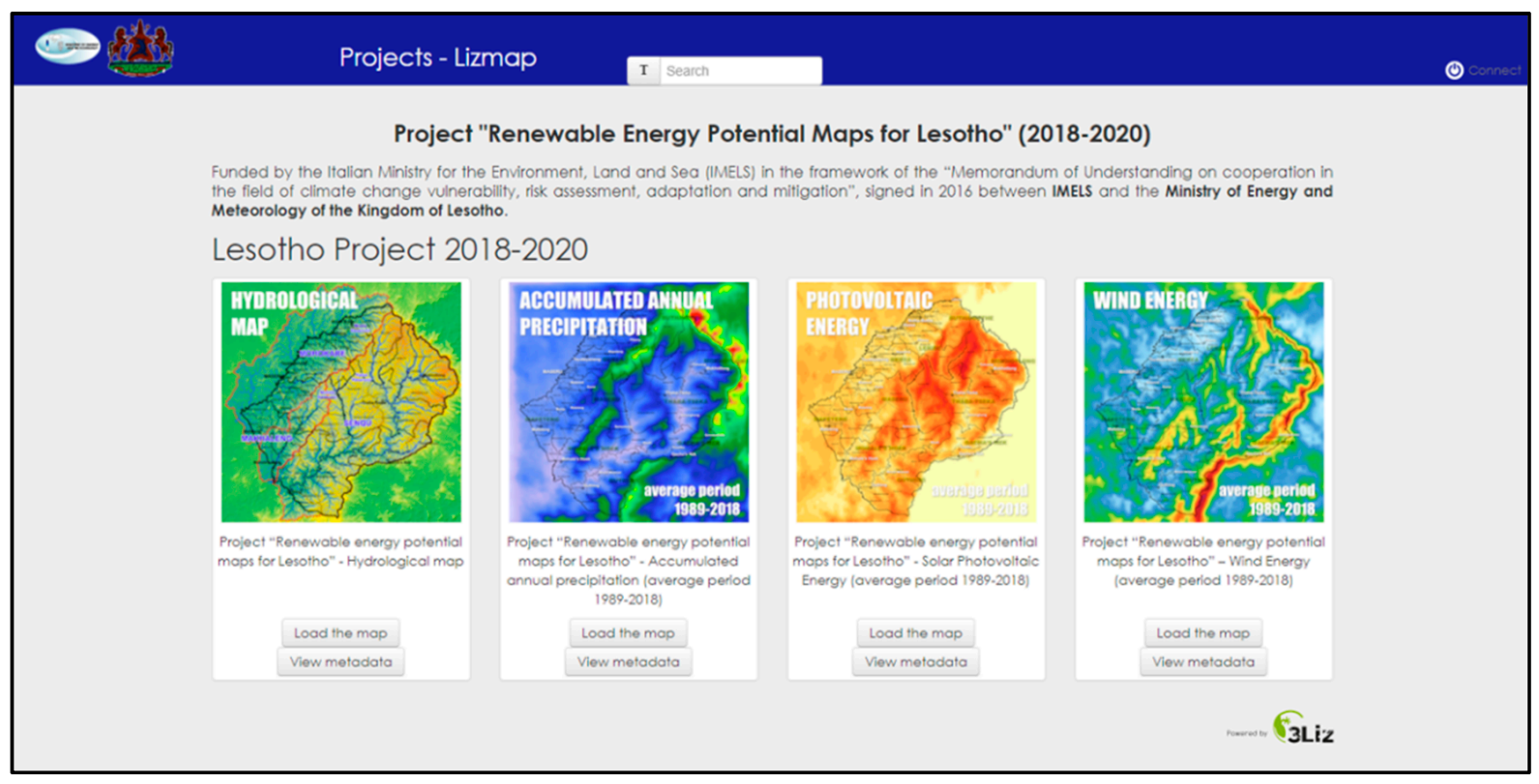

Figure 7. Main graphical user interface (GUI) of the WebGIS tool.

Each WebGIS section includes all the products made available within the project and developed according to the methodologies described in Section 3. Indeed, some short information about the data layers embedded in each section can be accessed by selecting "View metadata". Together with spatial description (based on both vector and raster layers), temporal information is included too. Namely, the 1989-2018 precipitation trend is available for every grid point. Concerning both photovoltaic and wind energy availability, interannual variability can be explored by means of additional maps providing some statistics computed over the 30-year period. Moreover, daily modulation and yearly variability of energy assessment can be investigated at every grid point, by means of heatmaps, based on the 1989-2018 averaging period.

A comprehensive list of all the available products is provided in Table 2, ordered by WebGIS sections. Both spatial data and temporal information (when available) are listed. More in detail, " $V$ " and " $R$ " are used to identify spatial data, based on vector and raster layers, respectively. " $\mathrm{T}$ " refers to a product investigating temporal information at every grid point. Finally, a list of other common useful ancillary data, available in all the sections, is provided at the end. 
Table 2. Data embedded into the developed WebGIS tool.

\begin{tabular}{|c|c|}
\hline Hydrological Map & \\
\hline Reservoirs & $\mathrm{V}$ \\
\hline Main Catchments & $\mathrm{V}$ \\
\hline Streams & $\mathrm{V}$ \\
\hline Sub-catchments (for each stream) & $\mathrm{V}$ \\
\hline \multicolumn{2}{|l|}{ Accumulated Annual Precipitation } \\
\hline Annual Precipitation & $\mathrm{R}$ \\
\hline 1989-2018 statistics: yearly averages, thirty-years average & \\
\hline Annual Precipitation Trend & $\mathrm{T}$ \\
\hline \multicolumn{2}{|l|}{ Photovoltaic Energy } \\
\hline Optimal Module Inclination Maximizing Annual PV power production & $\mathrm{R}$ \\
\hline Annual Global Solar Irradiation on panel surface unit & \\
\hline 1989-2018 statistics: average, minimum, maximum, standard deviation & $\mathrm{K}$ \\
\hline Annual Photovoltaic Power & $\mathrm{R}$ \\
\hline 1989-2018 statistics: average, minimum, maximum, standard deviation & K \\
\hline Heatmaps of Hourly Global Solar Irradiation & $\mathrm{T}$ \\
\hline Heatmaps of Hourly Photovoltaic Power & $\mathrm{T}$ \\
\hline \multicolumn{2}{|l|}{ Wind Energy } \\
\hline \multicolumn{2}{|l|}{ Wind Speed } \\
\hline Assessment heights: 50 m, 100 m, 150 m, 200 m a.g.l. & $\mathrm{R}$ \\
\hline \multirow{2}{*}{\multicolumn{2}{|c|}{$\begin{array}{c}\text { 1989-2018 statistics: average, minimum, maximum, standard deviation } \\
\text { Wind Power Density }\end{array}$}} \\
\hline & \\
\hline Assessment heights: 50 m, 100 m, 150 m, 200 m a.g.l. & $\mathrm{R}$ \\
\hline \multicolumn{2}{|l|}{$\begin{array}{c}\text { 1989-2018 statistics: average, minimum, maximum, standard deviation } \\
\text { Annual Turbine Wind Energy Production * }\end{array}$} \\
\hline \multirow{2}{*}{\multicolumn{2}{|c|}{$\begin{array}{l}\text { Annual Turbine Wind Energy Production * } \\
\text { 1989-2018 statistics: average, minimum, maximum, standard deviation }\end{array}$}} \\
\hline & \\
\hline \multicolumn{2}{|l|}{ Annual Turbine Capacity Factors * } \\
\hline 1989-2018 statistics: average, minimum, maximum, standard deviation & \\
\hline Wind Roses & $\mathrm{T}$ \\
\hline Heatmaps of Hourly Wind Power Density & $\mathrm{T}$ \\
\hline \multicolumn{2}{|l|}{ Common Ancillary Data } \\
\hline Digital Elevation Model of Lesotho (10 m resolution within Lesotho territory) & $\mathrm{R}$ \\
\hline Administrative Boundaries (State, Districts, Councils) & $\mathrm{V}$ \\
\hline Main Cities & $\mathrm{V}$ \\
\hline
\end{tabular}

\subsubsection{Potential and Perspectives of the Developed WebGIS Tool}

The aim of the developed WebGIS tool is to assist local experts and technicians in gathering and managing comprehensive information on REs in an interactive and integrated way. This provides local authorities with an essential input to the decision-making process in the planning and development of RE exploitation strategies.

The main potential of the system consists in the highly interactive access to a considerable amount of data layers. In more detail, the possibility of simultaneously exploring different informative layers allows an easy collection of several pieces of information, to support the identification of locations or areas more suitable for RE development or, conversely, to point out restrictions or spatial constraints. Moreover, concerning solar and wind power resources, the availability of temporal information provides for each point of the domain a quick identification of the period both of the year and of the day with maximum energy availability. These features can be overlaid with electricity demand curves or qualitative information about the timing of the peak load, providing an essential input in choosing or rejecting a location. As for the hydrological map, it is understood that the investigation on the possible siting for hydroelectric power stations is a complex task that requires detailed site-specific studies including different subjects (e.g., hydrological features of the soils, water consumption, geology, technical constraints, economic and social issues etc.) that could 
not be addressed at the scale of this project. However, the stream reaches and catchments boundaries in digital vector format, integrated with topography and mean rainfall information can be used for the first-approximation assessments of annual maximum productivity at watershed scale, as illustrated for example purposes in [78].

Examples of WebGIS user navigation and data retrieval from different maps are illustrated in Figures 8-10.

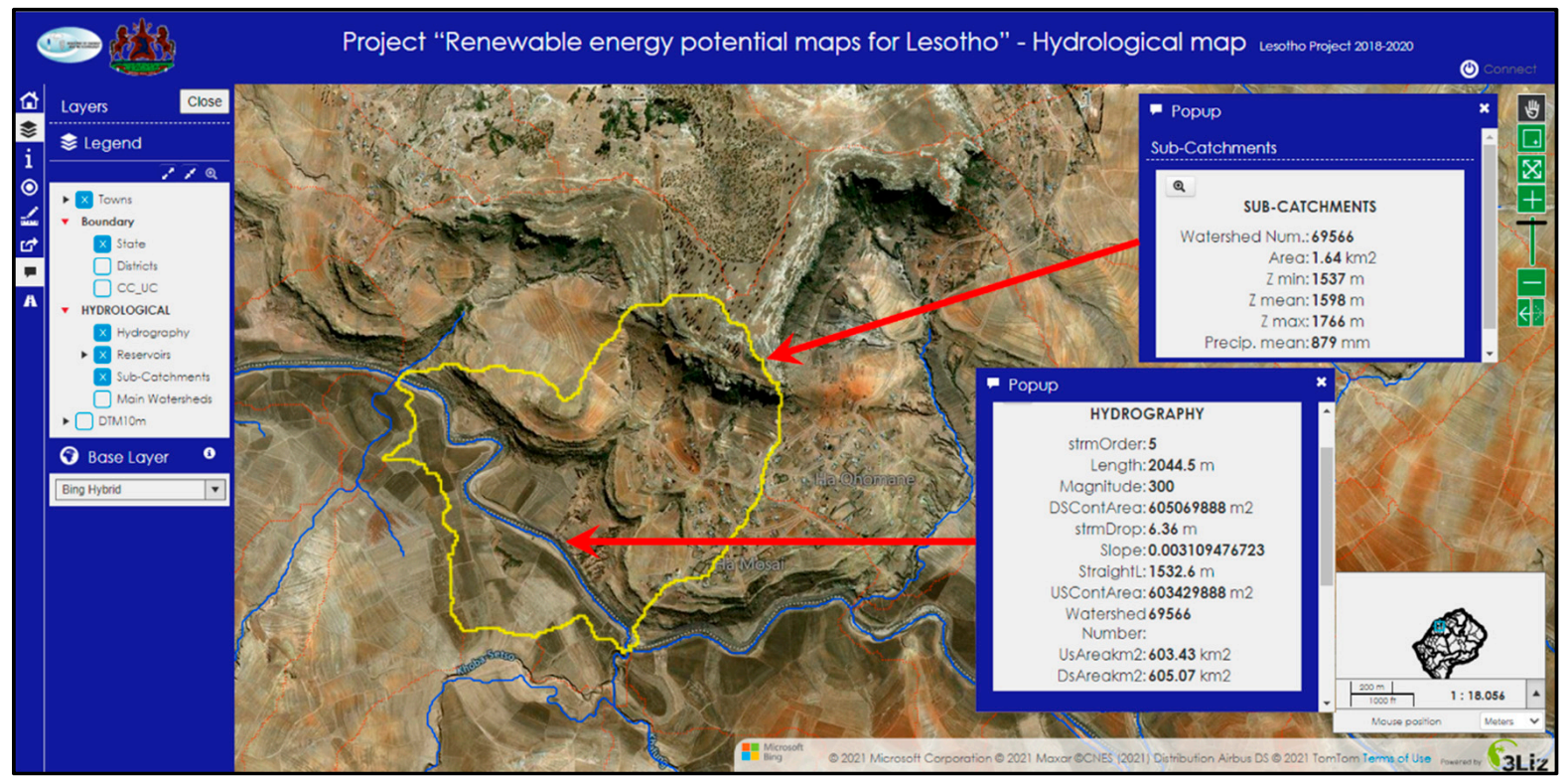

Figure 8. Hydrological map. For a given stream and relative sub-catchment, the user may retrieve information on geometry, topography, hierarchy and mean annual rainfall.

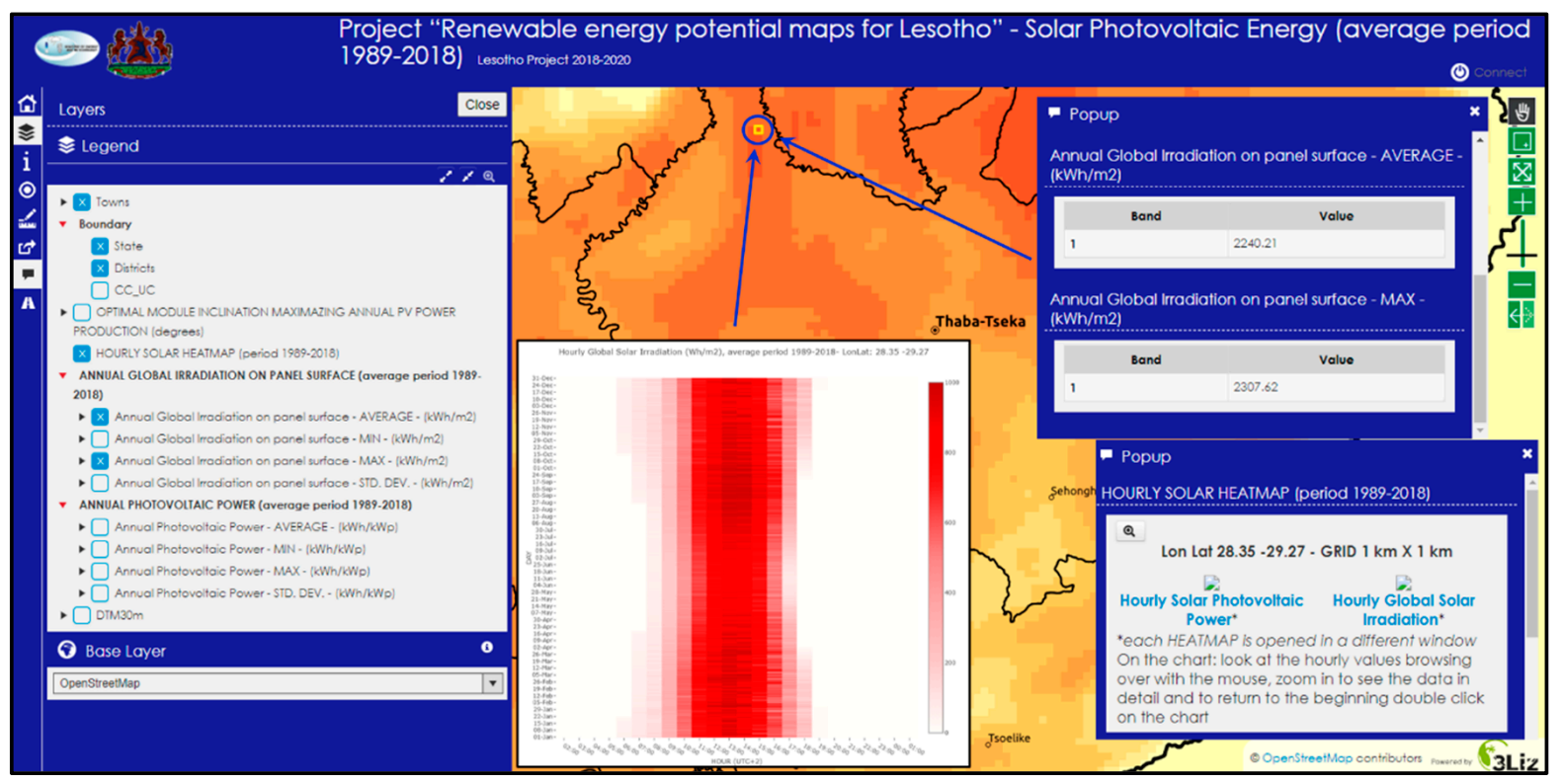

Figure 9. Photovoltaic energy map. In this example, the user derives information on average/maximum annual global solar irradiation in a given cell of the grid, together with its daily modulation and yearly variability. 


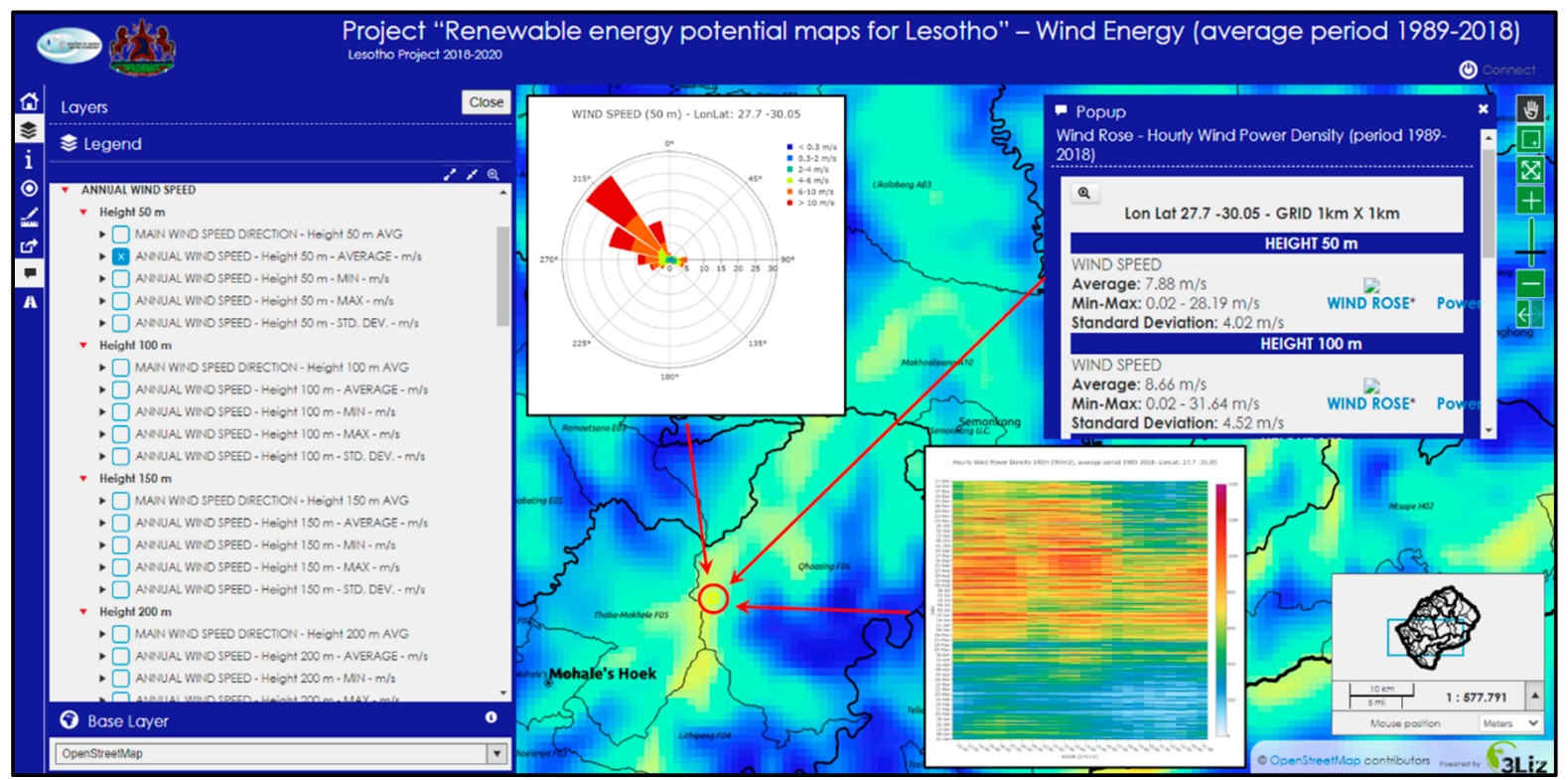

Figure 10. Wind energy map. In this example, the user derives statistics of wind speed at different heights, the wind rose, the daily modulation and yearly variability of wind power density in a given cell of the grid.

Apart from exploring the data produced in the framework of the project, the flexibility of the developed tool allows an expert user (logged in with administrator privileges) to add other useful data layers. For example, more detailed information (e.g., soil type, seismic instability, accessibility, distance to infrastructure or urban areas, population density, etc.) can be added in order to better assess spatial constraints in RE exploitation [85]. Very useful information to be added in the WebGIS would be the spatial distribution of the electrical load for different needs (households, industrial, etc.) that would be a key driver in the decision process of RE development. Moreover, new elaborations from currently available or new data layers can be added, too. For example, advantage can be taken of the availability of 30 years of hourly data of both solar and wind power energy potentials. Fields of spatial pattern of correlation in time of solar and wind energy availability can be computed [61] and embedded into the WebGIS in order to assess spatial distribution of the complementarity of these two resources in time. This information is useful in identifying the best sites where solar and wind energy installations can be co-located. Indeed, a high level of complementarity is preferable, since it allows an optimal integration in the electricity grid, minimising intermittent production and avoiding production higher than the demand. Another example is reported in [86], in which vector hydrographic data, land cover and geological data, along with historical sediment transport data at given gauging stations were used to propose a statistical regression model to estimate suspended sediment yield at ungauged catchments.

Furthermore, relying on a web platform, accessible to several users, makes it easy to exchange and share information among the different participants involved in the RE planning decision process. Indeed, the availability of the developed interactive web tool has the potential to facilitate and coordinate informed decisions within and among several stakeholder groups.

\subsection{Human Capacity Building}

Human capacity building was the natural conclusion of the project "Renewable energy potential maps for Lesotho". This activity focused on the use of the products of the project, maps and GIS database/WebGIS tool, for the managing and planning of renewable energy source exploitation in order to strengthen the local expertise and ability to undertake climate change mitigation actions. Two different sessions of human capacity building were carried out at the end of the project, in Maseru, capital city of Lesotho: 
- An intensive four days training course for 30 technicians and experts to describe in detail the renewable energy potential maps, the GIS database and the WebGIS tool.

- A one-day workshop for 20 stakeholders and managers to present and broadly illustrate the renewable energy potential maps and the WebGIS tool.

\subsubsection{Four-Day Training Course}

The training course was dedicated to local experts/technicians with a reasonable mathematical background (i.e., engineers, physicists, geologists); most of them were from the Ministry of Energy and Meteorology-Department of Energy and the Lesotho Meteorological Services, the two official beneficiaries of the project, but also other key institutions in charge of land/water/energy management were represented. Moreover, it is worth mentioning the presence of members of the National University of Lesotho, who demonstrated a deep scientific interest in the discussed topics.

Lectures were tailored both as front teachings and student-centered lessons with interactions among learners and teachers through discussions, practical exercises and case studies. Throughout the training the processed database and the maps were illustrated in detail and the methodologies, used to obtain all the products, were extensively explained. The course provided a brief introduction to geographic information systems (GIS) as a background and then it described in detail the GIS database of the project and the implemented WebGIS tool. The rationale for the upgrade and storage of the ancillary information contained in the database was addressed, while a special attention was dedicated to the use of the WebGIS tool through practical demonstrations. The attendees were able to open and practice the tool using their own laptops or mobile devices with real time interactions with the lecturers on their specific needs and requirements. Some dedicated exercises were also carried out using open-source GIS software QGIS, freely installed on the laptops. Some thematic layers and data collected during the project were customized and briefly processed by the participants in order to have a hint of the used procedures and the potentiality of the available products. In particular, the use of GIS specialized tools for hydrological applications was interactively explained through sessions in which participants were invited to perform specific computations on sample areas. Much time was dedicated to a questions and answers session and the discussion. In Figure 11 glimpses of a lecture and an exercise are illustrated.

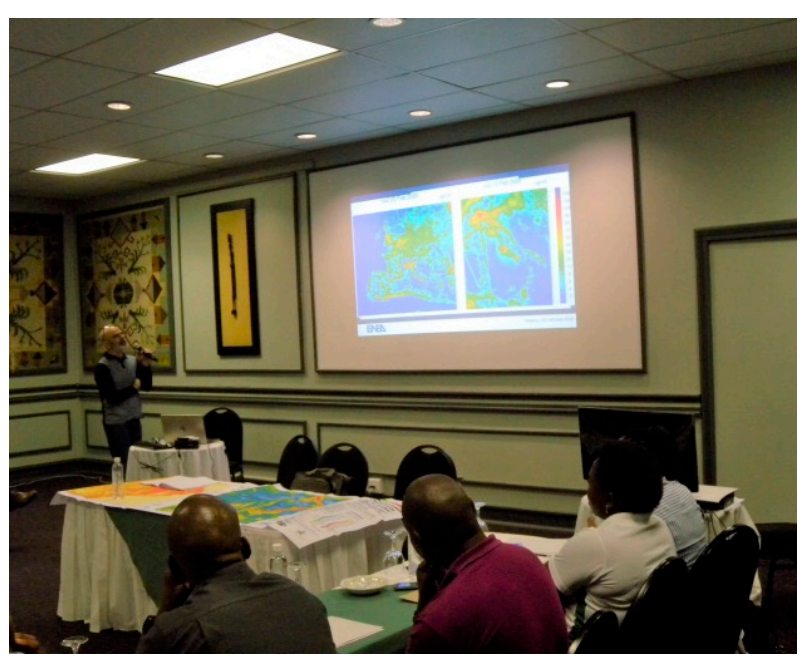

(a)

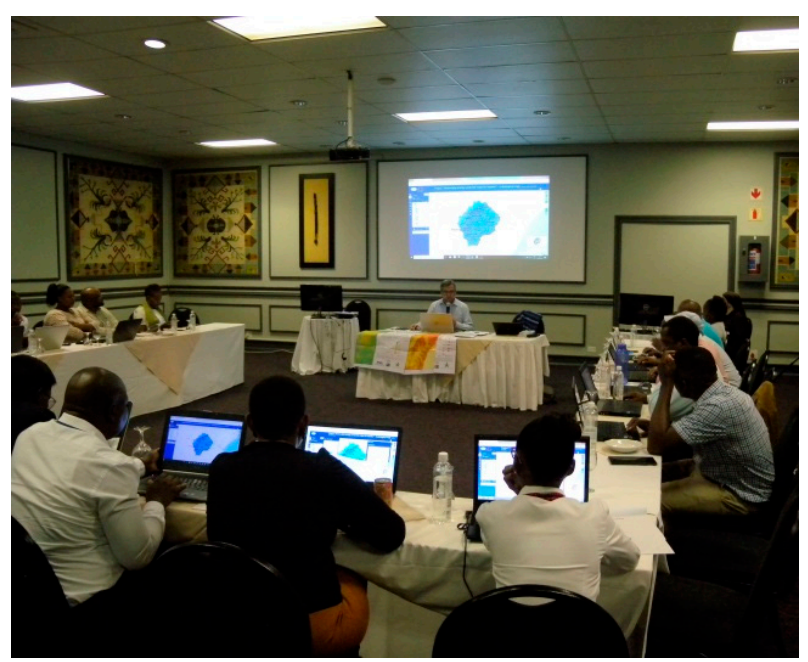

(b)

Figure 11. Training course for local experts. (a) Lecture; (b) exercise.

A good and fruitful interaction and discussions were established during both the applied exercises and the more theoretical lectures; several questions were raised, giving the opportunity to deepen some scientific aspects and to exchange ideas for further implemen- 
tation and follow-up studies. In some cases, trainees presented highlights of their current research and projects they are working on, asking for advice, suggestions, bibliographical references. At the end of the training, the educational material, including for example the presentations in pdf format and some videos, was delivered to all the trainees. A certification of attendance was also given to all participants. On the last day of the training, an anonymous feedback questionnaire was distributed to all the participants in order to collect their comments and advice. The questionnaire was composed of seven closed questions and an empty space for free comments and suggestions. Generally, a very good evaluation of the training as a whole and an overall satisfaction about the lessons arose from the answers, along with some room for improvements: actually, some comments reported the wish of an extension of the training at least for one more week, in order to deepen some technical topics and to consolidate the understanding of the new insights.

\subsubsection{One-Day Workshop for Stakeholders}

A workshop was dedicated to local stakeholders and decision makers who were interested in the output of the "Renewable energy potential maps for Lesotho" project. Participants belonged from the following Institutions: Ministry of Energy and Meteorology, Lesotho Meteorological Services, Lesotho Highlands Development Authority, Lesotho Electricity Company, Lesotho Electricity and Water Authority, Department of Water Affairs, Land Management, Department of Mines and Geology. An overview of the methodologies used to derive the photovoltaic power potential map, the wind power density map and the hydrological map was carried out. Then, the GIS processed database and the WebGIS as a tool to manage and plan renewable energy source exploitation were described; furthermore, the rationale for the upgrade and storage of the ancillary information contained in the database was briefly addressed. Finally, a questions and answers session was performed focusing on some scientific topics and in particular on the exchange of information modalities. Stakeholders demonstrated a deep interest in using the tool for planning the exploitation of renewable energy resources in their country.

\section{Conclusions and Recommendations}

The 2-year project "Renewable Potential Energy Maps for Lesotho" was implemented during the period March 2018-March 2020 in the framework of the PA and of the MoU between Italy and Lesotho on cooperation in the field of climate change vulnerability, risk assessment, adaptation and mitigation.

The main aim of the project was to establish a knowledge base and provide GIS tools that could support Lesotho's institutions and stakeholders in planning electricity production from RE sources. In fact, Lesotho currently has a deficit in local electricity production that could be significantly reduced by the exploitation of RE sources abundantly available in the country (hydro, solar, and wind).

The technical-scientific core of the project entailed the construction of a wind energy map, a solar energy map and a hydrological map covering the whole country, that were embedded in an interactive WebGIS. The maps and the WebGIS were produced using state-of-the-art numerical models, GIS tools and server software. Numerical meteorological simulations were performed using a high-performance computing infrastructure. Ancillary geographical data were also provided.

Specific training courses aiming at human capacity building and technology transfer were dedicated to local experts and administrators at different levels. Fruitful interactions were established between Italian and Lesotho's teams and an overall good degree of satisfaction was noticed among participants in the training course. The use of free and open-source software was specifically intended to allow the local experts to implement updates of the database and WebGIS according to their future needs and data availability. Indeed, the WebGIS tool represents also a basic framework for further investigations such as the environmental impact assessments of RE exploitation, which was out of the scope of the described project. 
Results of the project confirmed the high potential of Lesotho in terms of RE sources, and the long-term vision of the energy policies established by Lesotho's institutions, essentially focused on RE to support electrification programmes and foster the sustainable social and economic development of the country avoiding an increase of greenhouse gas emissions, under the auspice of the U.N. Agenda 2030.

The rather limited extent of the territory (at least compared to the size of most African states) allowed it to perform the project at national scale, which is one of the few examples in the region. However, the multidisciplinary approach of the project could be replicated, adapted and scaled-up to different developing countries in Sub-Saharan Africa and in other regions of the world. More generally, the outcomes of the projects could be of interest for scholars, practitioners and planners dealing with international cooperation, energy planning and sustainable development.

Author Contributions: Conceptualization and Writing original draft: F.P., G.R., M.D. and L.V.; Methodology, Formal Analysis and Investigation: F.P., M.D., L.V., G.B., S.G., C.T. and L.M.; Validation: M.M., M.L., M.R. and M.S.; Project Administration and Supervision: M.D., G.R. and G.Z.; Funding Acquisition: G.Z., M.M., M.R.; Writing Review and Editing: F.P., G.R., M.D., L.V. and G.B. All authors have read and agreed to the published version of the manuscript.

Funding: This research was carried out within the project "Renewable energy potential maps for Lesotho" (CUP:I31I18001000001) funded by the Italian Ministry for the Environment, Land and Sea (currently Ministry for Ecological Transition) in the framework of the "Memorandum of Understanding on cooperation in the field of climate change vulnerability, risk assessment, adaptation and mitigation", signed in 2016 between IMELS and the Ministry of Energy and Meteorology of the Kingdom of Lesotho. The article processing charge was funded by the Italian National Agency for New Technologies, Energy and Sustainable Economic Development (ENEA).

Institutional Review Board Statement: Not applicable.

Informed Consent Statement: Not applicable.

Acknowledgments: The authors wish to thank personnel from the Italian Ministry for the Environment, Land and Sea (currently Ministry for Ecological Transition, Roma, Italy) for assisting and providing useful advice especially in the initial phase of the project. Special thanks are addressed to local institutions: Land Administration Authority, (Maseru, Lesotho); Department of Water Affairs, (Maseru, Lesotho); Lesotho Highlands Development Authority, (Maseru, Lesotho); Department of Mines and Geology, (Maseru, Lesotho); Bureau of Statistics, (Maseru, Lesotho); Ministry of Public Works, Infrastructures and Transport, (Maseru, Lesotho); National University of Lesotho, (Roma, Lesotho) and FAO (Roma, Italy) for sharing datasets, reports and information which represented the fundamental inputs of the work. The Authors also sincerely thank personnel from the Department of Energy and Lesotho Meteorological Services who provided support and assistance. The computing resources and the related technical support used for the meteorological simulations were provided by CRESCO/ENEAGRID High-Performance Computing infrastructure and its staff $[62,63]$, funded by ENEA, and by Italian and European research programmes.

Conflicts of Interest: The authors declare no conflict of interest.

$\begin{array}{ll}\text { Abbreviations } & \\ \text { AEP } & \text { Accumulated Energy Production } \\ \text { BoS } & \text { Bureau of Statistics (Lesotho) } \\ \text { CF } & \text { Capacity Factors } \\ \text { COP } & \text { Conference Of Parties } \\ \text { CPU } & \text { Central Processing Unit } \\ \text { CRESCO } & \text { Computational RESsearch Centre on COmplex systems } \\ \text { CUP } & \text { Codice Unico di Progetto (in Italian) i.e., a Project Identification Code } \\ \text { DEM } & \text { Digital Elevation Model } \\ \text { DWA } & \text { Department of Water Affairs (Lesotho) } \\ \text { ECMWF } & \text { European Centre for Medium-Range Weather Forecasts }\end{array}$




$\begin{array}{ll}\text { ENEA } & \text { Italian National Agency for New Technologies, Energy and Sustainable } \\ \text { ERA5 } & \text { Economic Development } \\ \text { the fifth generation ECMWF atmospheric reanalysis of the global climate } \\ \text { GHGs } & \text { Food and Agriculture Organization of the United Nations } \\ \text { GIS } & \text { GreenHouse Gases } \\ \text { GUI } & \text { Geographic Information System } \\ \text { HPC } & \text { Graphical User Interface } \\ \text { IEC } & \text { High Performance Computer } \\ \text { IMELS } & \text { International Electrotechnical Commission } \\ \text { LAA } & \text { Italian Ministry for the Environment, Land and Sea } \\ \text { LEC } & \text { Land Administration Authority (Lesotho) } \\ \text { LHDA } & \text { Lesotho Electricity Company } \\ \text { LHWP } & \text { Lesotho Highlands Development Authority } \\ \text { LMS } & \text { Lesotho Highlands Water Project } \\ \text { LREBRE } & \text { Lesotho Meteorological Services } \\ \text { NCAR } & \text { Lesotho Renewable Energy-Based Rural Electrification Project } \\ \text { PA } & \text { National Center for Atmospheric Research } \\ \text { PV } & \text { Paris Agreement } \\ \text { RE } & \text { PhotoVoltaic } \\ \text { SDG } & \text { Renewable Energy } \\ \text { SREP } & \text { Sustainable Development Goal } \\ \text { SRTM } & \text { Scaling Up Renewable Energy Program in Low Income Countries } \\ \text { UNFCCC } & \text { Shuttle Radar Topography Mission } \\ \text { USGS } & \text { United Nations Framework Convention on Climate Change } \\ \text { UTC } & \text { United States Geological Survey } \\ \text { WHO } & \text { Universal Time Coordinated } \\ \text { WPD } & \text { World Health Organization } \\ \text { WRF } & \text { Wind Power Density } \\ & \text { Weather Research and Forecasting } \\ & \end{array}$

\section{References}

1. Land Cover Atlas of Lesotho; FAO, Food and Agriculture Organization of the United Nations: Rome, Italy, 2017.

2. 2016 Lesotho Population and Housing Census, Analytical Report, Vol. IIIA: Population Dynamics; Bureau of Statistics: Maseru, Lesotho, 2018.

3. AQUASTAT Country Profile —Lesotho; FAO, Food and Agriculture Organization of the United Nations: Rome, Italy, 2005.

4. Lesotho Highlands Development Authority. Available online: http://www.lhda.org.ls/lhdaweb (accessed on 1 July 2021).

5. Klunne, W.J. Small Hydropower in Southern Africa-An Overview of Five Countries in the Region. J. Energy South. Afr. 2013, 24, 14-25. [CrossRef]

6. Lesotho Electricity Company. Available online: https://www.lec.co.ls/ (accessed on 1 July 2021).

7. Mpholo, M.; Nchaba, T.; Monese, M. Yield and Performance Analysis of the First Grid-Connected Solar Farm at Moshoeshoe I International Airport, Lesotho. Renew. Energy 2015, 81, 845-852. [CrossRef]

8. Arthur, L.J.; Darby, A.W.; Rafoneke, B. Lesotho Highlands Water Project: Design and layout of underground works for 'Muela Hydropower Project. In Tunnelling '94: Papers Presented at the Seventh International Symposium, 'Tunnelling'94'; Arthur, L.J., Darby, A.W., Rafoneke, B., Daws, G., MacDonald, D., Innaurato, N., Mancini, R., Rondena, E., Zaninetti, A., Coutts, A.W.P., et al., Eds.; Springer: Boston, MA, USA, 1994; pp. 3-13, ISBN 978-1-4615-2646-9.

9. Danisovic, I.; Jurisch, D.; Maran, L.; Garner, D.; Seckel, A.; Stock, R. Construction and Commissioning of the Muela Hydropower Project. Tunn. Undergr. Space Technol. 1999, 14, 55-66. [CrossRef]

10. Herschy, R.W. Katse Dam: Lesotha Highlands Water Project. In Encyclopedia of Lakes and Reservoirs; Bengtsson, L., Herschy, R.W., Fairbridge, R.W., Eds.; Springer: Dordrecht, The Netherlands, 2012; pp. 421-423, ISBN 978-1-4020-4410-6.

11. Keketso, L. The Mixed Blessings of the Lesotho Highlands Water Project. Mt. Res. Dev. 2003, 23, 7-10. [CrossRef]

12. Wentworth, L. Lesotho Highlands: Water Woes or Win-Wins? (PERISA Case Study 4: Infrastructure); South African Institute of International Affairs: Johannesburg, South Africa; European Centre for Development Policy Management: Maastricht, The Netherlands, 2013.

13. United Nations, Department of Economic and Social Affairs, Statistics Division: Energy Statistics Database. Available online: https:/ / unstats.un.org/unsd/energystats/data/ (accessed on 1 July 2021).

14. 2019 Energy Report; Statistical Report No.10: 2020; Bureau of Statistics: Maseru, Lesotho, 2020.

15. Annual Report 2016-2017; Lesotho Electricity Company: Maseru, Lesotho, 2017.

16. Tracking SDG7: The Energy Progress Report. Available online: https://trackingsdg7.esmap.org/ (accessed on 1 July 2021).

17. Senatla, M.; Nchake, M.; Taele, B.M.; Hapazari, I. Electricity Capacity Expansion Plan for Lesotho-Implications on Energy Policy. Energy Policy 2018, 120, 622-634. [CrossRef]

18. 2017 Energy Balances; United Nations, Department of Economic and Social Affairs, Statistics Division: New York, NY, USA, 2020. 
19. 2017 Household Energy Consumption Survey Statistical Tables; Bureau of Statistics: Maseru, Lesotho, 2017.

20. World Health Organization. Household Air Pollution and Health. Available online: https://www.who.int/news-room/factsheets/detail/household-air-pollution-and-health (accessed on 1 July 2021).

21. Alfstad, T. Development of a Least Cost Energy Supply Model for the SADC Region. Graduation Thesis, Master of Science in Engineering, University of Cape Town, Cape Town, South Africa, 2004.

22. Taele, B.M.; Gopinathan, K.K.; Mokhuts'oane, L. The Potential of Renewable Energy Technologies for Rural Development in Lesotho. Renew. Energy 2007, 32, 609-622. [CrossRef]

23. Taele, B.M.; Mokhutšoane, L.; Hapazari, I.; Tlali, S.B.; Senatla, M. Grid Electrification Challenges, Photovoltaic Electrification Progress and Energy Sustainability in Lesotho. Renew. Sustain. Energy Rev. 2012, 16, 973-980. [CrossRef]

24. Spalding-Fecher, R.; Senatla, M.; Yamba, F.; Lukwesa, B.; Himunzowa, G.; Heaps, C.; Chapman, A.; Mahumane, G.; Tembo, B.; Nyambe, I. Electricity Supply and Demand Scenarios for the Southern African Power Pool. Energy Policy 2017, 101, 403-414. [CrossRef]

25. Mpholo, M.; Meyer-Renschhausen, M.; Thamae, R.I.; Molapo, T.; Mokhuts'oane, L.; Taele, B.M.; Makhetha, L. Rural Household Electrification in Lesotho. In Africa-EU Renewable Energy Research and Innovation Symposium 2018 (RERIS 2018); Mpholo, M., Steuerwald, D., Kukeera, T., Eds.; Springer International Publishing: Cham, Switzerland, 2018; pp. 97-103.

26. Lesotho Renewable Energy-Based Rural Electrification Project (LREBRE). DRAFT Terminal Evaluation Report; Government of Lesotho: Maseru, Lesotho; Global Environmental Facility: Washington, DC, USA; United Nations Development Programme: New York, NY, USA, 2013.

27. Scaling-Up Renewable Energy Program in Low Income Countries (SREP). Investment Plan for Lesotho; Ministry of Energy and Meteorology, Department of Energy: Maseru, Lesotho, 2017.

28. Lesotho Vision 2020; Government of Lesotho: Maseru, Lesotho, 2000.

29. Lesotho Energy Policy 2015-2025; Government of Lesotho: Maseru, Lesotho, 2015.

30. Lesotho's National Climate Change Policy; Ministry of Energy and Meteorology: Maseru, Lesotho, 2017.

31. National Strategic Development Plan II. 2018/19-2022/23; Government of Lesotho: Maseru, Lesotho, 2018.

32. Jensen, T. Hydroelectric Power in Lesotho; Publication No. 3; Norwegian Water Resources and Energy Administration: Oslo, Norway, 1987.

33. Taele, B.M.; Mokhutšoane, L.; Hapazari, I. An Overview of Small Hydropower Development in Lesotho: Challenges and Prospects. Renew. Energy 2012, 44, 448-452. [CrossRef]

34. Klunne, W.J. Lesotho. In World Small Hydropower Development Report 2019; Liu, D., Liu, H., Wang, X., Kremere, E., Eds.; United Nations Industrial Development Organization: Vienna, Austria; International Center on Small Hydro Power: Hangzhou, China, 2019.

35. Gopinathan, K.K. The Distribution of Global and Sky Radiation throughout Lesotho. Sol. Wind Technol. 1988, 5, 103-106. [CrossRef]

36. Gopinathan, K.K. Solar Energy Utilization in Lesotho. RERIC Int. Energy J. 1989, 11, 61-68.

37. Gopinathan, K.K.; Soler, A. Diffuse Radiation Models and Monthly-Average, Daily, Diffuse Data for a Wide Latitude Range. Energy 1995, 20, 657-667. [CrossRef]

38. Gopinathan, K.K.; Maliehe, N.B.; Mpholo, M.I. A Study on the Intercepted Insolation as a Function of Slope and Azimuth of the Surface. Energy 2007, 32, 213-220. [CrossRef]

39. IRENA-International Renewable Energy Agency. Global Atlas for Renewable Energy. Available online: https://www.irena.org/ globalatlas (accessed on 1 July 2021).

40. Mpholo, M.; Mathaba, T.; Letuma, M. Wind Profile Assessment at Masitise and Sani in Lesotho for Potential Off-Grid Electricity Generation. Energy Convers. Manag. 2012, 53, 118-127. [CrossRef]

41. Mathaba, T.; Mpholo, M.; Letuma, M. Velocity and Power Density Analysis of the Wind at Letšeng-La-Terae in Lesotho. Renew. Energy 2012, 46, 210-217. [CrossRef]

42. Paris Agreement; United Nations: Paris, France, 2015.

43. United Nations Framework Convention on Climate Change. Available online: https:// unfccc.int/ (accessed on 1 July 2021).

44. Transforming Our World: The 2030 Agenda for Sustainable Development; United Nations: New York, NY, USA, 2015.

45. United Nations, Department of Economic and Social Affairs. Sustainable Development. Available online: https://sdgs.un.org/ (accessed on 1 July 2021).

46. Tinker, I. The Real Rural Energy Crisis: Women's Time. Energy J. 1987, 8, 125-146. [CrossRef]

47. Sulich, A.; Sołoducho-Pelc, L.; Ferasso, M. Management Styles and Decision-Making: Pro-Ecological Strategy Approach. Sustainability 2021, 13, 1604. [CrossRef]

48. Serrano-Gomez, L.; Muñoz-Hernandez, J.I. Risk Influence Analysis Assessing the Profitability of Large Photovoltaic Plant Construction Projects. Sustainability 2020, 12, 9127. [CrossRef]

49. Jimenez, P.A.; Hacker, J.P.; Dudhia, J.; Haupt, S.E.; Ruiz-Arias, J.A.; Gueymard, C.A.; Thompson, G.; Eidhammer, T.; Deng, A. WRF-Solar: Description and Clear-Sky Assessment of an Augmented NWP Model for Solar Power Prediction. Bull. Am. Meteorol. Soc. 2016, 97, 1249-1264. [CrossRef]

50. Skamarock, W.C.; Klemp, J.B.; Dudhia, J.; Gill, D.O.; Barker, D.; Duda, M.G.; Huang, X.; Wang, W.; Powers, J.G. A Description of the Advanced Research WRF Version 3; National Center for Atmospheric Research: Boulder, CO, USA, 2008.

51. Haupt, S.E.; Kosovic, B.; Jensen, T.; Lazo, J.K.; Lee, J.A.; Jimenez, P.A.; Cowie, J.; Wiener, G.; McCandless, T.C.; Rogers, M.; et al Building the Sun4Cast System: Improvements in Solar Power Forecasting. Bull. Am. Meteorol. Soc. 2018, 99, 121-136. [CrossRef] 
52. Cornejo, L.; Martín-Pomares, L.; Alarcon, D.; Blanco, J.; Polo, J. A through Analysis of Solar Irradiation Measurements in the Region of Arica Parinacota, Chile. Renew. Energy 2017, 112, 197-208. [CrossRef]

53. Lee, J.A.; Haupt, S.E.; Jiménez, P.A.; Rogers, M.A.; Miller, S.D.; McCandless, T.C. Solar Irradiance Nowcasting Case Studies near Sacramento. J. Appl. Meteorol. Climatol. 2017, 56, 85-108. [CrossRef]

54. Verbois, H.; Huva, R.; Rusydi, A.; Walsh, W. Solar Irradiance Forecasting in the Tropics Using Numerical Weather Prediction and Statistical Learning. Sol. Energy 2018, 162, 265-277. [CrossRef]

55. De Jong, P.; Dargaville, R.; Silver, J.; Utembe, S.; Kiperstok, A.; Torres, E.A. Forecasting High Proportions of Wind Energy Supplying the Brazilian Northeast Electricity Grid. Appl. Energy 2017, 195, 538-555. [CrossRef]

56. Wang, Z.; Duan, C.; Dong, S. Long-Term Wind and Wave Energy Resource Assessment in the South China Sea Based on 30-Year Hindcast Data. Ocean Eng. 2018, 163, 58-75. [CrossRef]

57. Prósper, M.A.; Otero-Casal, C.; Fernández, F.C.; Miguez-Macho, G. Wind Power Forecasting for a Real Onshore Wind Farm on Complex Terrain Using WRF High Resolution Simulations. Renew. Energy 2019, 135, 674-686. [CrossRef]

58. Penchah, M.M.; Malakooti, H. The Eastern-Iran Wind-Resource Assessment through a Planetary Boundary Layer Simulation (2011_2015). Wind Eng. 2020, 44, 253-265. [CrossRef]

59. ARW Version 3 Modeling System's User's Guide; National Center for Atmospheric Research: Boulder, CO, USA, 2014.

60. Hersbach, H.; Bell, B.; Berrisford, P.; Hirahara, S.; Horányi, A.; Muñoz-Sabater, J.; Nicolas, J.; Peubey, C.; Radu, R.; Schepers, D.; et al. The ERA5 Global Reanalysis. Q. J. R. Meteorol. Soc. 2020, 146, 1999-2049. [CrossRef]

61. D'Isidoro, M.; Briganti, G.; Vitali, L.; Righini, G.; Adani, M.; Guarnieri, G.; Moretti, L.; Raliselo, M.; Mahahabisa, M.; Ciancarella, L.; et al. Estimation of Solar and Wind Energy Resources over Lesotho and Their Complementarity by Means of WRF Yearly Simulation at High Resolution. Renew. Energy 2020, 158, 114-129. [CrossRef]

62. Iannone, F.; Ambrosino, F.; Bracco, G.; Rosa, M.D.; Funel, A.; Guarnieri, G.; Migliori, S.; Palombi, F.; Ponti, G.; Santomauro, G.; et al. CRESCO ENEA HPC Clusters: A Working Example of a Multifabric GPFS Spectrum Scale Layout. In Proceedings of the 2019 International Conference on High Performance Computing \& Simulation (HPCS), Dublin, Ireland, 15 July 2019 ; pp. $1051-1052$.

63. CRESCO: Computational RESsearch Centre on COmplex Systems. Available online: https://www.eneagrid.enea.it/CRESCOportal/ (accessed on 1 July 2021).

64. Saxena, B.K.; Rao, K.V.S. Estimation of Wind Power Density at a Wind Farm Site Located in Western Rajasthan Region of India. Procedia Technol. 2016, 24, 492-498. [CrossRef]

65. Wilkinson, L.; Friendly, M. The History of the Cluster Heat Map. Am. Stat. 2009, 63, 179-184. [CrossRef]

66. Monforti, F.; Huld, T.; Bódis, K.; Vitali, L.; D’Isidoro, M.; Lacal-Arántegui, R. Assessing Complementarity of Wind and Solar Resources for Energy Production in Italy. A Monte Carlo Approach. Renew. Energy 2014, 63, 576-586. [CrossRef]

67. La Gennusa, M.; Nucara, A.; Pietrafesa, M.; Rizzo, G. A Model for Managing and Evaluating Solar Radiation for Indoor Thermal Comfort. Sol. Energy 2007, 81, 594-606. [CrossRef]

68. Mousavi Maleki, S.A.; Hizam, H.; Gomes, C. Estimation of Hourly, Daily and Monthly Global Solar Radiation on Inclined Surfaces: Models Re-Visited. Energies 2017, 10, 134. [CrossRef]

69. Liu, B.; Jordan, R. Daily Insolation on Surfaces Tilted towards Equator. Trans. ASHRAE 1961, 67, 526-541.

70. Martin, N.; Ruiz, J.M. Calculation of the PV Modules Angular Losses under Field Conditions by Means of an Analytical Model. Sol. Energy Mater. Sol. Cells 2001, 70, 25-38. [CrossRef]

71. Martin, N.; Ruiz, J.M. Corrigendum to "Calculation of the PV Modules Angular Losses under Field Conditions by Means of an Analytical Model" [Sol. Energy Mater. Sol. Cells 70 (1) (2001) 25-38]. Sol. Energy Mater. Sol. Cells 2013, 110, 154. [CrossRef]

72. Huld, T.; Friesen, G.; Skoczek, A.; Kenny, R.P.; Sample, T.; Field, M.; Dunlop, E.D. A Power-Rating Model for Crystalline Silicon PV Modules. Sol. Energy Mater. Sol. Cells 2011, 95, 3359-3369. [CrossRef]

73. Huld, T.; Amillo, A.M.G. Estimating PV Module Performance over Large Geographical Regions: The Role of Irradiance, Air Temperature, Wind Speed and Solar Spectrum. Energies 2015, 8, 5159-5181. [CrossRef]

74. Faiman, D. Assessing the Outdoor Operating Temperature of Photovoltaic Modules. Prog. Photovolt. Res. Appl. 2008, 16, 307-315. [CrossRef]

75. QGIS. A Free and Open Source Geographic Information System. Available online: http:/ / www.qgis.org (accessed on 1 July 2021).

76. Tarboton, D. Terrain Analysis Using Digital Elevation Models in Hydrology. In Proceedings of the 23rd ESRI International Users Conference, San Diego, CA, USA, 7 July 2003.

77. David Tarboton Hydrology Research Group, Utah State University Terrain Analysis Using Digital Elevation Models (TauDEM) Version 5. Available online: http://hydrology.usu.edu/taudem/taudem5/index.html (accessed on 1 July 2021).

78. Pasanisi, F.; Grauso, S.; Tebano, C.; Mahahabisa, M.; Raliselo, M. Producing a Digital Hydrographic Map Aiming at Renewable Energy Potential Mapping of Lesotho. J. Appl. Eng. Sci. 2020, 10, 61-68. [CrossRef]

79. USGS Earth Resources Observation and Science (EROS) Archive-Digital Elevation. Shuttle radar topography mission (SRTM) 1 Arc-Second global. US Geol. Surve 2015. [CrossRef]

80. Farr, T.G.; Rosen, P.A.; Caro, E.; Crippen, R.; Duren, R.; Hensley, S.; Kobrick, M.; Paller, M.; Rodriguez, E.; Roth, L.; et al. The Shuttle Radar Topography Mission. Rev. Geophys. 2007, 45. [CrossRef]

81. USGS, U.S. Geological Survey EarthExplorer. Available online: https:/ / earthexplorer.usgs.gov/ (accessed on 1 July 2021).

82. O'Callaghan, J.F.; Mark, D.M. The Extraction of Drainage Networks from Digital Elevation Data. Comput. Vis. Graph. Image Process. 1984, 28, 323-344. [CrossRef] 
83. Apache HTTP Server Project. Available online: https:/ /httpd.apache.org/ (accessed on 1 July 2021).

84. 3Liz. Available online: https://www.3liz.com/en/ (accessed on 1 July 2021).

85. Calvert, K.; Pearce, J.M.; Mabee, W.E. Toward Renewable Energy Geo-Information Infrastructures: Applications of GIScience and Remote Sensing That Build Institutional Capacity. Renew. Sustain. Energy Rev. 2013, 18, 416-429. [CrossRef]

86. Grauso, S.; Pasanisi, F.; Tebano, C. Modeling the Suspended Sediment Yield in Lesotho Rivers. Modeling Earth Syst. Environ. 2020, 6, 759-768. [CrossRef] 